\title{
PROBABILITY DISTRIBUTIONS OF WIND SPEED IN THE CAMPO GRANDE, MS, BRAZIL
}

\author{
SOUZA, Amaury de - amaury.souza@ufms.br \\ Universidade Federal de Mato Grosso do Sul / UFMS \\ BOUZAHIR, Hassane - h.bouzahir@uiz.ac.ma \\ Ibn Zohr University / Agadir, Morocco \\ TIZGUI, Ijjou - ijjou.tizgui@yahoo.com \\ Ibn Zohr University / Agadir, Morocco \\ GUEZAR, Fatima El - fatima.elguezar@yahoo.fr \\ Ibn Zohr University / Agadir, Morocco \\ OZONUR, Deniz - denizozonur01@gmail.com \\ Gazi University / Ankara, Turkey
}

\begin{abstract}
The objective of this work was to evaluate the adjustment of data of average wind velocity to Campo Grande, State of Mato Grosso do Sul, to the distributions of probability of: Weibull (W2), Ralyeigh (RAY), Log-Logistic (LL), Inverse Gaussian (IG), Normal (N), Gamma (G), Generalized extreme value (GEV), Extreme value (EV), Lognormal (LN), Logistic (L), Burr (BR) and Rician (R). Four statistical criteria, coefficient of determination (R2), mean square error (RMSE), mean absolute error (MAE) and mean absolute percentage error (MAPE) are considered as judgment criteria to evaluate the adequacy of probability density functions. As a result, Weibull, Rayleigh, generalized extreme value, extreme value, and Rician distributions accurately perform data. These distributions can be used as an alternative distribution that adequately describes wind speed data in Campo Grande. The weaker settings are obtained by the normal, Burr, logistic, log-logistic, and inverse Gaussian distributions.
\end{abstract}

KEYWORDS: Probability density function; wind speed distribution; Goodness of fit tests.

DISTRIBUIÇÕES DE PROBABILIDADE DA VELOCIDADE DO VENTO EM CAMPO GRANDE, $M S, B R A S I L$

RESUMO: Resumo- Os objetivos deste trabalho foram avaliar o ajuste de dados horários de

velocidade média do vento para Campo Grande, Estado do Mato Grosso do Sul, às distribuições de probabilidade de: Weibull (W2), Ralyeigh (RAY), Log-Logística (LL), Gaussiana Inversa (IG), Normal (N), Range (G), Extremamente Gerada (GV), Extrema (EV), Lognormal (LN), Logística (L), Burr(BR) e Rician (R). Quatro critérios estatísticos, coeficiente de determinação (R2), erro quadrático médio (RMSE), erro absoluto médio (MAE) e erro absoluto médio (MAPE) foram considerados como critérios de julgamento para avaliar a adequação das funções de densidade de probabilidade. Como resultado, Weibull, Rayleigh, valor extremo generalizado, valor extremo e distribuições ricianas executam dados com precisão. Essas distribuições podem ser usadas como uma distribuição alternativa que descreve adequadamente os dados de velocidade do vento em Campo Grande. As configurações mais fracas foram obtidas pelas distribuições Normal, Burr, Logística, Log-Logística e Gaussiana Inversa.

PALAVRAS-CHAVE: Função de densidade de probabilidade; Distribuição da velocidade do vento; Testes de qualidade de ajuste.

DISTRIBUCIONES DE PROBABILIDAD DE LA VELOCIDAD DEL VIENTO EN CAMPO GRANDE, MS, BRASIL 
RESUMEN: Los objetivos de este trabajo fueron evaluar el ajuste de datos de velocidad media del viento para Campo Grande, Estado de Mato Grosso do Sul, a las distribuciones de probabilidad de: Weibull (W2), Ralyeigh (RAY), Log-Logística (LL), Gaussiana Inversa (IG), Normal (N), Range (G), Extremamente Gerada (GV), Extrema (EV), Lognormal (LN), Logística (L), Burr (BR) e Rician (R). Cuatro criterios estadísticos, coeficiente de determinación (R2), error cuadrático medio (RMSE), error absoluto medio (MAE) y error absoluto promedio (MAPE), se consideran criterios de juicio para evaluar la idoneidad de las funciones de densidad de probabilidad. Como resultado, Weibull, Rayleigh, el valor extremo generalizado, el valor extremo y las distribuciones Rician realizan con precisión los datos. Estas distribuciones se pueden usar como una distribución alternativa que describe adecuadamente los datos de velocidad del viento en Campo Grande. Las configuraciones más débiles se obtienen mediante las distribuciones Normal, Burr, Logística, Log-Logística y Gaussiana Inversa.

PALABRAS-CLAVE: función de densidad de probabilidade; distribución de la velocidad del viento; pruebas de bondad de ajuste.

\section{I.INTRODUCTION}

The use of probability density functions is directly linked to the nature of the data to which they relate. Some have good estimation capacity for small numbers of data, others require a large number of observations. Probability density functions (pdfs) are generally used to characterize wind speed observations. The adaptation of several pdfs has been investigated in several regions of the world and few works have been developed in Brazil with adjustments of these functions.

The Weibull distribution of 2 parameters and the Rayleigh distribution are the most commonly used pdfs in the wind speed data analysis AYODELE TR, JIMOH AA, MUNDA JL, AGEE JT, 2012; IRWANTO M, GOMESH N, MAMAT MR, YUSOFF YM, 2014; MIRHOSSEINI M, SHARIFI F, SEDAGHAT A, 2011; ORDÓÑEZ G, OSMA G, VERGARA P, REY J., 2014; TULLER SE, BRETT AC., 1985; AKPINAR EK, AKPINAR S., 2005; CELIK AN, 2003; HENNESSEY JP, 1977]. Weibull is a flexible distribution. It presents a good fit, it requires only the estimation of 2 parameters; and it is simple. The Rayleigh distribution, a distribution of one parameter, is a special case of the 2-parameter Weibull is most often used alongside the 2-parameter Weibull in studies related to wind speed analysis.

A large number of studies have been published concerning the use of a variety of probability density functions ( $p d f s$ ) to describe wind speed probability distributions, including the beta function, gamma function, lognormal function, logistical function, Rayleigh function, and Weibull function [CHANG TP, 2011; WU J, WANG JZ, CHI DZ, 2013]. Among these, the Weibull distribution is the most frequently used one for modeling wind speed (typical monthly or annually) due to its two flexible parameters. The Weibull shape parameter describes the width of the data distribution; the scale parameter controls the abscissa scale of the plot of data distribution [CHANG TP, 2011].

Several statistics (goodness-of-fit tests) related to wind speed analysis have been used in the cited studies in order to compare the proposed pdfs to sample wind speed data distribution. A review of the most frequently used ones is presented by [OUARDA, TBM], CHARRON C, CHEBANA F, 2016]. Authors have reported the advantages and disadvantages of many criteria namely, the loglikelihood, the coefficient of determination, the Akaike and the Bayesian Information Criteria, the root mean square error, the Kolmogorov-Smirnov test statistic, the Chi-square test statistic and the Anderson-Darling test statistic. In 
most studies, to assess the adequacy of the studied pdfs, a visual assessment of fitted pdfs superimposed on the histograms of wind speed data is also performed [CHANG TP, 2011; LI M, LI X, 2015; JARAMILLO OA, SALDAÑA R, MIRANDA U., 2004; KOSE R, OZGUR MA, ERBAS O, TUGCU A., 2004].

In this study, we focused on determining the best statistical model that describes the wind regime in Campo Grande, state of Mato Grosso do Sul, Brazil. This model provides vital information for assessing wind power potential.For this, a comparison of the probability distributions considered with the distributions of measurements is made to demonstrate its adequacy in the description of the wind speed characteristics. We used the coefficient of determination, the mean square error [AKPINAR EK, AKPINAR S., 2005; AUWERA L, MEYER F, MALET L., 1980; CHANG TP, 2011; JUSTUS CG, HARGRAVES WR, MIKHAIL A, GRAB D, 1978; SAFETY JV, LAMBERT TW., 2000 (USA)], mean absolute error (MAE) and mean absolute error (MAPE).

\section{II - MATERIAL AND METHODS}

2-parameters Weibull, Ralyeigh, Log-Logistic, Inverse Gaussian, Normal, Gamma, Generalized extreme value, Extreme value, Lognormal, Logistic, Burr and Rician probability distributions were used to model the Mato Grosso do Sul data sets. Performance indicators are calculated by comparing observed values to predicted values. The observed values are the classified values of the monitoring data, while the predicted values are the values obtained from the adjusted distribution.

\section{MEASUREMENT OF DATA}

The wind data used in this study were obtained from the Center for Monitoring Water Resources and Climate of the State of Mato Grosso do Sul CEMTEC-MS. Geographic coordinates of the meteorological stations where the wind speed data were captured at a height of $10 \mathrm{~m}$ by the Belford-three-cup type anemometer are given in Table 1 . The uncertainty at $95 \%$ confidence intervals was determined as $\pm 2 \%$. The used wind speed data is observed per day throughout the year from 2013 to 2017. We didn't note any failure in the anemometer during the wind speed measurement. The recorded wind speeds were calculated as the average wind speed for each month. It has been found that the use of the monthly wind speed has some limitations, such as loss of extremely high or low wind speeds in the month, as well as the inability to observe diurnal variations in wind speed. However, the use of the average monthly wind speed, which is available, can be used to study seasonal changes in wind speed and facilitate analysis of wind data.

Table 1 - Geographical coordinates of the measurement site.

\begin{tabular}{|c|c|c|c|c|c|}
\hline City & Latitude & Longitude & $\begin{array}{c}\text { Altitude } \\
(\mathrm{m})\end{array}$ & $\begin{array}{c}\text { Area } \\
\left(\mathrm{km}^{2}\right)\end{array}$ & $\begin{array}{c}\text { Measuring } \\
\text { period }\end{array}$ \\
\hline $\begin{array}{c}\text { Campo } \\
\text { Grande }\end{array}$ & $20^{\circ} 26^{\prime} 34^{\prime} \mathrm{S}$ & $54^{\circ} 38^{\prime} 47 " \mathrm{~W}$ & 532 & 8118,4 & $\begin{array}{c}\text { Jan to Dec } \\
2013 / 2017\end{array}$ \\
\hline
\end{tabular}




\section{PROBABILITY DISTRIBUTIONS}

In this study the effectiveness of twelve one-component probability distributions are evaluated. We have used the one-component parametric pdfs because our data present a unimodal distribution. These twelve models have been selected among other one-component models due to their successful applications according to the literature. The used pdfs as well as their cumulative distribution functions (cdfs) and the number of their parameters (N) are presented in Table 2.

Table 2 - List of used pdfs, their cdfs and number of parameters.

\begin{tabular}{|c|c|c|c|c|}
\hline Name & pdf & cdf & $\mathrm{N}$ & Nomenclature \\
\hline W2 & $f(v)=\left(\frac{k}{c}\right)\left(\frac{v}{c}\right)^{k-1} \exp \left(-\left(\frac{v}{c}\right)^{k}\right)$ & $\mathrm{F}(\mathrm{v})=1-\exp \left(-\left(\frac{\mathrm{v}}{\mathrm{c}}\right)^{\mathrm{k}}\right)$ & 2 & $\begin{array}{l}\mathrm{c} \text { is the scale parameter } \\
\text { and } \mathrm{k} \text { is the shape } \\
\text { parameter }\end{array}$ \\
\hline RAY & $f(v)=\frac{2 v}{c^{2}} \exp \left(-\left(\frac{v}{c}\right)^{2}\right)$ & $\mathrm{F}(\mathrm{v})=1-\exp \left(-\left(\frac{\mathrm{v}}{\mathrm{c}}\right)^{2}\right)$ & 1 & $\mathrm{c}$ is the scale parameter \\
\hline LL & $f(v)=\frac{\exp \left(\frac{\ln v-\mu}{\sigma}\right)}{\sigma v\left[1+\exp \left(\frac{\ln v-\mu}{\sigma}\right)\right]^{2}}$ & $\mathrm{~F}(\mathrm{v})=\frac{1}{1+\exp \left(\frac{\ln (\mathrm{v})-\mu}{\sigma}\right)}$ & 2 & $\begin{array}{l}\mu \text { and } \sigma \text { are log location } \\
\text { and log scale parameters, } \\
\text { respectively }\end{array}$ \\
\hline IG & $f(v)=\left(\frac{\lambda}{2 \pi v^{3}}\right)^{\frac{1}{2}} \exp \left(-\frac{\lambda(v-\mu)^{2}}{2 v \mu^{2}}\right)$ & $\begin{array}{l}\mathrm{F}(\mathrm{v}) \\
=\Phi\left[\sqrt{\frac{\lambda}{\mathrm{v}}}\left(\frac{\mathrm{v}}{\mu}-1\right)\right] \\
+\Phi\left[-\left(\frac{\mathrm{v}}{\mu}+1\right)\right] \exp \left(\frac{2 \lambda}{\mu}\right)\end{array}$ & 2 & $\begin{array}{l}\lambda, \mu \text { and } \Phi \text { are the shape } \\
\text { parameter and the scale } \\
\text { parameter and the error } \\
\text { function respectively. }\end{array}$ \\
\hline $\mathrm{N}$ & $f(v)=\frac{1}{\sigma \sqrt{2 \pi}} \exp \left(-\frac{(v-\mu)^{2}}{2 \sigma^{2}}\right)$ & $\mathrm{F}(\mathrm{v})=\frac{1}{2}\left(1+\operatorname{erf}\left(\frac{\mathrm{v}-\mu}{\sigma \sqrt{2}}\right)\right)$ & 2 & $\begin{array}{l}\mu=\text { mean (location } \\
\text { parameter) } \\
\sigma=\text { variance } \\
\text { (squared } \underline{\text { scale) }}\end{array}$ \\
\hline G & $f(v)=\frac{v^{\alpha-1}}{\Gamma(\alpha) \beta^{\alpha}} \exp \left(-\frac{v}{\beta}\right)$ & $\mathrm{F}(\mathrm{v})=\frac{\gamma\left(\alpha, \frac{\mathrm{v}}{\beta}\right)}{\Gamma(\alpha)}$ & 2 & $\begin{array}{l}\alpha, \beta, \Gamma \text { and } \gamma \text { are the shape } \\
\text { parameter, scale } \\
\text { parameter, the gamma } \\
\text { function, and the } \\
\text { incomplete gamma } \\
\text { function respectively. }\end{array}$ \\
\hline GEV & $\begin{array}{l}\mathrm{f}(\mathrm{v})=\frac{1}{\sigma} \mathrm{t}(\mathrm{v})^{\mathrm{k}+1} \exp (-\mathrm{t}(\mathrm{v})) \\
\text { where } \\
\left.\mathrm{t}(\mathrm{v})=\left(1-\mathrm{k}\left(\frac{\mathrm{v}-\mu}{\sigma}\right)\right) \frac{1}{\mathrm{k}}\right], \mathrm{k} \neq 0 \\
\mathrm{f}(\mathrm{v})=\exp \left(-\left(\frac{\mathrm{v}-\mu}{\sigma}\right)\right) \mathrm{k}=0\end{array}$ & $\mathrm{~F}(\mathrm{v})=\exp (-\mathrm{t}(\mathrm{v}))$ & 3 & $\begin{array}{l}\mu, \sigma \text { and } k \text { are the } \\
\text { location, scale and shape } \\
\text { parameters respectively. }\end{array}$ \\
\hline EV & $f(v)=\frac{1}{\sigma} \exp \left[-\frac{v-\mu}{\sigma}-\exp \left(\frac{v-\mu}{\sigma}\right)\right]$ & $\mathrm{F}(\mathrm{v})=\exp \left[-\exp \left(-\frac{\mathrm{v}-\mu}{\alpha}\right)\right]$ & 2 & $\begin{array}{l}\mu \text { is the } \\
\text { location parameter and } \\
\sigma \text { is the scale parameter. }\end{array}$ \\
\hline
\end{tabular}




\begin{tabular}{|l|l|l|l|l|}
\hline LN & $\mathrm{f}(\mathrm{v})=\frac{1}{\sigma \sqrt{2 \pi}} \exp \left(-\frac{(\ln \mathrm{v}-\mu)^{2}}{2 \sigma^{2}}\right)$ & $\mathrm{F}(\mathrm{v})=\varphi\left(\frac{\ln \mathrm{v}-\mu}{\sigma}\right)$ & 2 & $\begin{array}{l}\mu \text { is the location } \\
\text { parameter, } \sigma \text { is the scale } \\
\text { parameter and } \varphi \text { is the } \\
\text { cumulative distribution } \\
\text { function of the standard } \\
\text { normal distribution. }\end{array}$ \\
\hline $\mathrm{L}$ & $\mathrm{f}(\mathrm{v})=\frac{\exp \left(-\frac{\mathrm{v}-\mu}{\sigma}\right)}{\sigma\left[1+\exp \left(-\frac{\mathrm{v}-\mu}{\sigma}\right)\right]^{2}}$ & $\mathrm{~F}(\mathrm{v})=\frac{1}{1+\exp \left(\frac{\mathrm{v}-\mu}{\sigma}\right)}$ & 2 & $\begin{array}{l}\mu \text { is the } \\
\text { location parameter and } \\
\sigma \text { is the scale parameter. }\end{array}$ \\
\hline $\mathrm{BR}$ & $\mathrm{f}(\mathrm{v})=\frac{\mathrm{akv} \mathrm{v}^{\mathrm{a}-1}}{\mathrm{c}^{\mathrm{a}}\left[1+\left(\frac{\mathrm{v}}{\mathrm{c}}\right)^{\mathrm{a}}\right]^{1+\mathrm{k}}}$ & $\mathrm{F}(\mathrm{v})=1-\left(1+\mathrm{v}^{\mathrm{a}}\right)^{-\mathrm{k}}$ & 3 & $\begin{array}{l}\text { c and k are the shape } \\
\text { parameters and a is the } \\
\text { scale parameter. }\end{array}$ \\
\hline $\mathrm{R}$ & $\mathrm{f}(\mathrm{v})=\frac{\mathrm{v}}{\sigma^{2}} \exp \left(\frac{-\left(\mathrm{v}^{2}+\gamma^{2}\right)}{2 \sigma^{2}} \mathrm{I}_{0}\left(\frac{\mathrm{v} \gamma}{\sigma^{2}}\right)\right.$ & $\mathrm{F}(\mathrm{v})=1-\mathrm{Q}_{1}\left(\frac{\gamma}{\sigma}, \frac{\mathrm{v}}{\sigma}\right)$ & 2 & $\begin{array}{l}\text { I } \text { is the zero-order } \\
\text { modified Bessel function } \\
\text { of the first kind. } Q_{1} \text { is the } \\
\text { Marcum Q-function. } \gamma \text { is } \\
\text { the noncentrality } \\
\text { parameter and } \sigma \text { is the } \\
\text { scale parameter. }\end{array}$ \\
\hline
\end{tabular}

\section{ESTIMATION OF DISTRIBUTIONS PARAMETERS}

Several methods can be used to estimate the considered distributions parameters [TIZGUI I, EL GUEZAR F, BOUZAHIR H, BENAID B, 2017]. However, the selection of effective distributions is more important compared to the selection of parameter estimation methods [MOHAMMADI $K$, ALAVI $O$, MCGOWAN J G., 2017]. In this work, the Maximum Likelihood method (ML) is applied. This method has shown good results in several studies. It gives the values of the parameters which maximize the probability of obtaining the observed data.

The likelihood function ( $L$ ) for a random sample of wind speed $v_{1}, v_{2}, \ldots, v_{n}$ and theoretical probability density function (f) with $j$ parameters $\alpha_{1} \ldots . \alpha_{j}$ is represented by equation:

$$
L=\prod_{i}^{n} f\left(v_{i} \cdot \alpha_{1} \ldots \alpha_{j}\right)
$$

For each parameter $\alpha_{i}, M L$ consists in estimating its value which maximizes the Likelihood function $(L)$ by solving the following equation.

$$
\frac{\mathrm{d} \log \mathrm{L}}{\mathrm{d} \alpha_{\mathrm{i}}}=0
$$




\section{ACCURACY TESTS}

The accuracy tests (or goodness of-fit tests) are essential to compare the observed climate distributions with the predicted / modelled distributions. The observed dataset is the set of values from the monitoring systems whereas the modelled datasets are obtained from the fitted distributions. In this study, two categories of goodness of-fit tests are used. $\mathrm{R}^{2}$ and RMSE associated with any pdf (which are calculated using the relative frequencies of the histogram and the predicted pdfs obtained by the theoretical model) and MAE and MAPE associated with cdf (which are calculated using the empirical cumulative frequencies of observations and the predicted cdf of the studied models). These accuracy tests are based on the histogram approach, in which the measurements are arranged in a relative frequency histogram with $\mathrm{N}$ class intervals. The advantage of this approach is that it is less affected by individual measurements [OUARDA T B M J, CHARRON C, CHEBANA F, 2016]. Their expressions are given below:

\subsection{The coefficient of determination $\left(R^{2}\right)$}

The coefficient of determination measures how much the variance of the measured data is explained by the theoretical model. In this work, $\mathrm{R}^{2}$ is calculated using at the class intervals the relative frequencies of the histogram and the predicted pdfs obtained by the theoretical model [OUARDA, TBM], CHARRON C, CHEBANA F., 2016]. $\mathrm{R}^{2}$ is expressed as follows:

$$
\mathrm{R}^{2}=1-\frac{\sum_{\mathrm{i}=1}^{\mathrm{N}}\left(\mathrm{p}_{\mathrm{i}}-\hat{\mathrm{p}}_{\mathrm{i}}\right)^{2}}{\sum_{\mathrm{i}=1}^{\mathrm{N}}\left(\mathrm{p}_{\mathrm{i}}-\overline{\mathrm{p}}\right)^{2}}
$$

where $\hat{p}_{i}$ is the predicted pdf at the $i^{\text {th }}$ interval, $p_{i}$ is the relative frequency at the $\mathrm{i}^{\text {th }}$ class and $\overline{\mathrm{p}}=\frac{1}{\mathrm{~N}} \sum_{\mathrm{i}=1}^{\mathrm{N}} \mathrm{p}_{\mathrm{i}}$ [CHANG TP., 2011].

\subsection{ROOT MEAN SQUARE ERROR (RMSE)}

Since, it combines the bias and the dispersion, the root means square error is an important indicator for comparing the predicted with the observed values. The RMSE associated with probabilities in class intervals is given as:

$$
\operatorname{RMSE}=\left[\frac{1}{\mathrm{~N}} \sum_{\mathrm{i}=1}^{\mathrm{N}}\left(\mathrm{p}_{\mathrm{i}}-\hat{\mathrm{p}}_{\mathrm{i}}\right)^{2}\right]^{\frac{1}{2}}
$$

\subsection{MEAN ABSOLUTE ERROR (MAE)}

The mean absolute error is defined as the mean of the absolute errors derived from the observed and predicted values. The mathematical equation of MAE associated with cdf in class intervals is defined as:

$$
\mathrm{MAE}=\frac{1}{\mathrm{~N}} \sum_{\mathrm{i}=1}^{\mathrm{N}}\left|\mathrm{F}_{\mathrm{i}}-\hat{\mathrm{F}}_{\mathrm{i}}\right|
$$


where $\widehat{F}_{i}$ is the theoretical cdf of the $i^{\text {th }}$ measured wind speed and $F_{i}$ is the empirical cdf of the measured wind speed at $\mathrm{i}^{\text {th }}$ time stage.

\subsection{MEAN ABSOLUTE PERCENTAGE ERROR (MAPE)}

The mean absolute percentage error indicates the mean absolute percentage difference between the predicted and observed data. Basing on the histogram approach, the mean absolute percentage error associated to the cdfs is calculated as [HU Q, WANG Y, XIE Z, ZHU P, YU D., 2016]:

$$
\text { MAPE }=\frac{1}{N} \sum_{i=1}^{N} \frac{\left|F_{i}-\widehat{F}_{i}\right|}{F_{i}} \times 100 \%
$$

\section{RESULTS AND DISCUSSIONS}

Table 3 presents the descriptive statistics of wind speed, including maximum, mean, minimum, median, standard deviation and asymmetry coefficient. The average wind speed varies from $2.27 \mathrm{~m} / \mathrm{s}$ (Dec 2017) to 4.09 $\mathrm{m} / \mathrm{s}$ (Jul 2017) with a monthly average of $(3,079 \pm 0,456) \mathrm{m} / \mathrm{s}$ and a median monthly average equal to $(3,075 \pm 0,472)$. The monthly standard deviation is low (between 0.11 and 0.39 ). It is weak enough, which means that most of measurements revolve around the average value. The coefficients of skewness are positive for Jan, Feb, Mar, Jul, Sep and Oct. Which indicates that those months distributions are right skewed. For other months, the coefficients of skewness are negative. Which mean that the long tail is on the negative side of the peak. The overall distribution has a positive asymmetry, concentration of data in lower values, the average will suffer influence of the right tail.

Table 3 shows the monthly variation of measurements for each year. The overall mean of measurements is $3.08 \mathrm{~m} / \mathrm{s}$, the maximum annual mean of wind speed is $3.012 \mathrm{~m} / \mathrm{s}$ (recorded in 2013) and the minimum is $3.02 \mathrm{~m} / \mathrm{s}$ (2015). All the annual averages are close to the overall average. All the annual averages are close to the overall average, that no significant variation in yearly mean wind speed was observed. For the considered period, we note that the monthly mean wind speed (Table 3 ) is lower in summer months (Jan to Mar) and the higher values were recorded in winter season (Jul to Sep). 
Table 3 - Descriptive analysis of wind speed for the sampling period (2013 to 2017).

\begin{tabular}{|l|l|l|l|l|l|l|l|l|l|l|l|l|}
\hline Year & Jan & Feb & Mar & Apr & May & Jun & Jul & Aug & Sep & Oct & Nov & Dec \\
\hline 2013 & 3.06 & 2.65 & 2.84 & 2.95 & 3.00 & 2.70 & 3.81 & 3.74 & 4.02 & 3.30 & 3.09 & 2.30 \\
\hline 2014 & 2.44 & 2.67 & 2.59 & 3.02 & 3.15 & 3.36 & 3.69 & 3.62 & 3.64 & 3.64 & 2.86 & 2.68 \\
\hline 2015 & 2.48 & 2.31 & 2.40 & 2.73 & 3.21 & 3.77 & 3.44 & 3.77 & 3.38 & 3.27 & 2.71 & 2.82 \\
\hline 2016 & 2.71 & 2.34 & 2.52 & 2.66 & 3.00 & 3.36 & 3.53 & 3.57 & 3.52 & 3.56 & 3.07 & 2.86 \\
\hline 2017 & 2.37 & 2.29 & 2.65 & 3.07 & 2.68 & 3.41 & 4.09 & 3.83 & 3.86 & 3.45 & 2.98 & 2.27 \\
\hline mean & 2.61 & 2.45 & 2.60 & 2.89 & 3.01 & 3.32 & 3.71 & 3.71 & 3.68 & 3.44 & 2.94 & 2.59 \\
\hline standard deviation & 0.28 & 0.19 & 0.16 & 0.18 & 0.21 & 0.39 & 0.25 & 0.11 & 0.26 & 0.16 & 0.16 & 0.28 \\
\hline Median & 2.48 & 2.34 & 2.59 & 2,95 & 3.00 & 3.36 & 3.69 & 3.74 & 3.64 & 3.45 & 2.98 & 2.68 \\
\hline minimum & 2.37 & 2.29 & 2.40 & 2.66 & 2.68 & 2.70 & 3.44 & 3.57 & 3.38 & 3.27 & 2.71 & 2.27 \\
\hline maximum & 3.06 & 2.67 & 2.84 & 3.07 & 3.21 & 3.77 & 4.09 & 3.83 & 4.02 & 3.64 & 3.09 & 2.86 \\
\hline Skewness & 1.30 & 0.58 & 0.52 & -0.45 & -1.16 & -1.05 & 0.72 & -0.31 & 0.26 & 0.08 & -0.80 & -0.38 \\
\hline
\end{tabular}

\section{PROBABILITY DISTRIBUTIONS AND THEIR PARAMETERS ESTIMATION}

The estimated parameters of the tested distributions are reported in Table 4. Those parameters are obtained using the ML under MATLAB software. Figures 1 and 2 present respectively the histogram of the monthly and annual mean wind speeds for the years 2013 to 2017 adjusted by the twelve studied probability density functions and its cumulated frequency adjusted by the twelve cumulative distribution functions.

Table 4 - Estimated parameters for the studied distributions.

\begin{tabular}{|c|c|c|c|c|c|c|}
\hline Function & W2 & RAY & $\mathrm{N}$ & G & LN & $\mathrm{L}$ \\
\hline $\begin{array}{l}\text { Parameter } \\
\text { Estimates }\end{array}$ & $\begin{array}{l}c=3.5386 \\
k=2.0343\end{array}$ & $\mathrm{k}=2.4934$ & $\begin{array}{ll}\mu & =3.1424 \\
\sigma & =1.5996\end{array}$ & $\begin{array}{l}a=3.1778 \\
\beta=0.9888\end{array}$ & $\begin{array}{l}\mu=0.9794 \\
\sigma=0.6596\end{array}$ & $\begin{array}{l}\mu=3.0376 \\
\sigma=0.8942\end{array}$ \\
\hline Function & $\mathrm{LL}$ & IG & GEV & $\mathrm{EV}$ & $\mathrm{BR}$ & $\mathrm{R}$ \\
\hline $\begin{array}{l}\text { Parameter } \\
\text { Estimates }\end{array}$ & $\begin{array}{l}\mu=1.0451 \\
\sigma=0.3352\end{array}$ & $\begin{array}{l}\mu=3.1424 \\
\lambda=4.6812\end{array}$ & $\begin{array}{l}\mathrm{k}=0.0760 \\
\sigma=1.3648 \\
\mu=2.4503\end{array}$ & $\begin{array}{l}\mu=3.9875 \\
\sigma=1.9178\end{array}$ & $\begin{array}{l}\mathrm{a}=13.0228 \\
\mathrm{c}=2.1155 \\
\mathrm{k}=16.4762\end{array}$ & $\begin{array}{ll}\mathrm{s} & =0.5291 \\
\sigma & =2.4660\end{array}$ \\
\hline
\end{tabular}



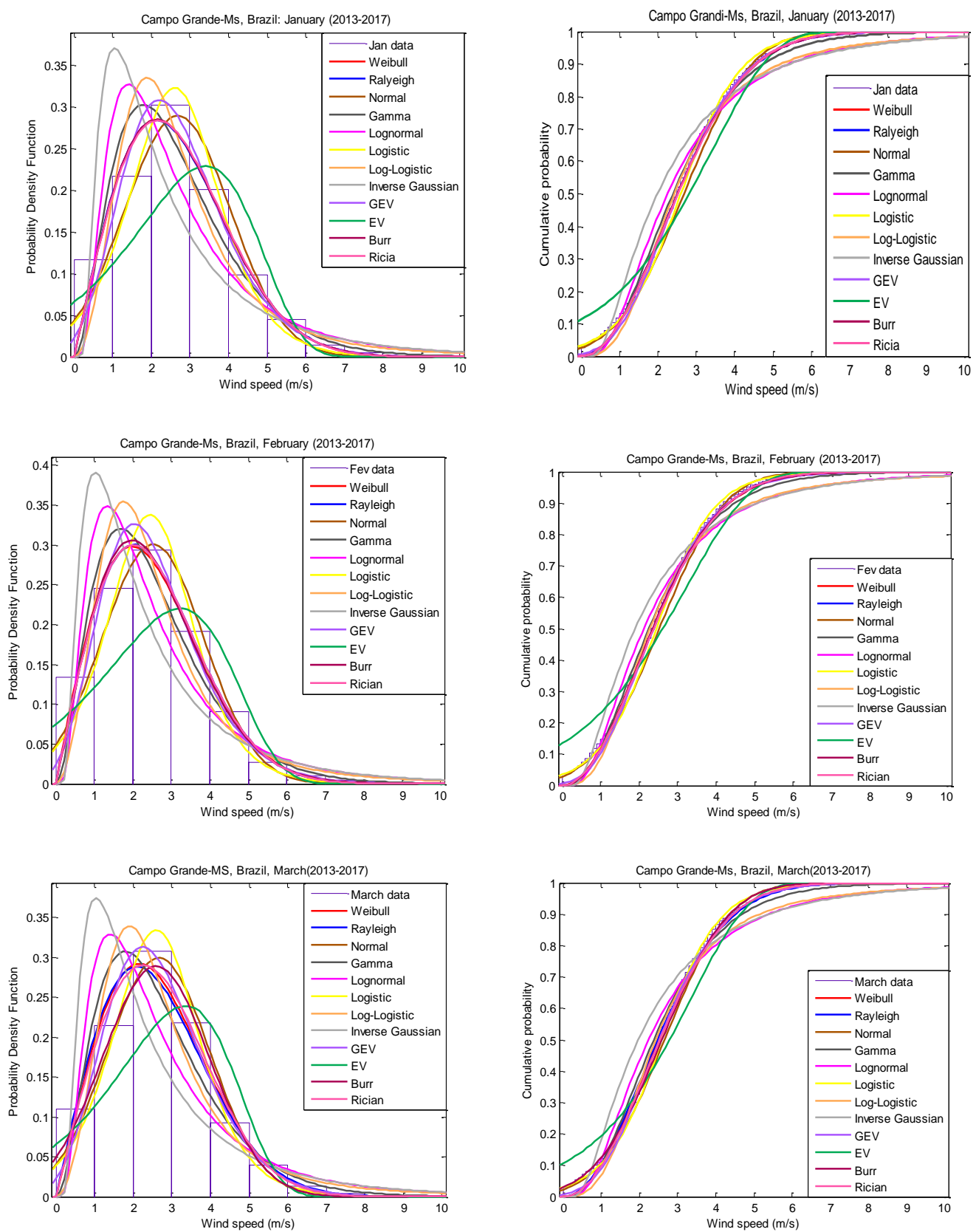

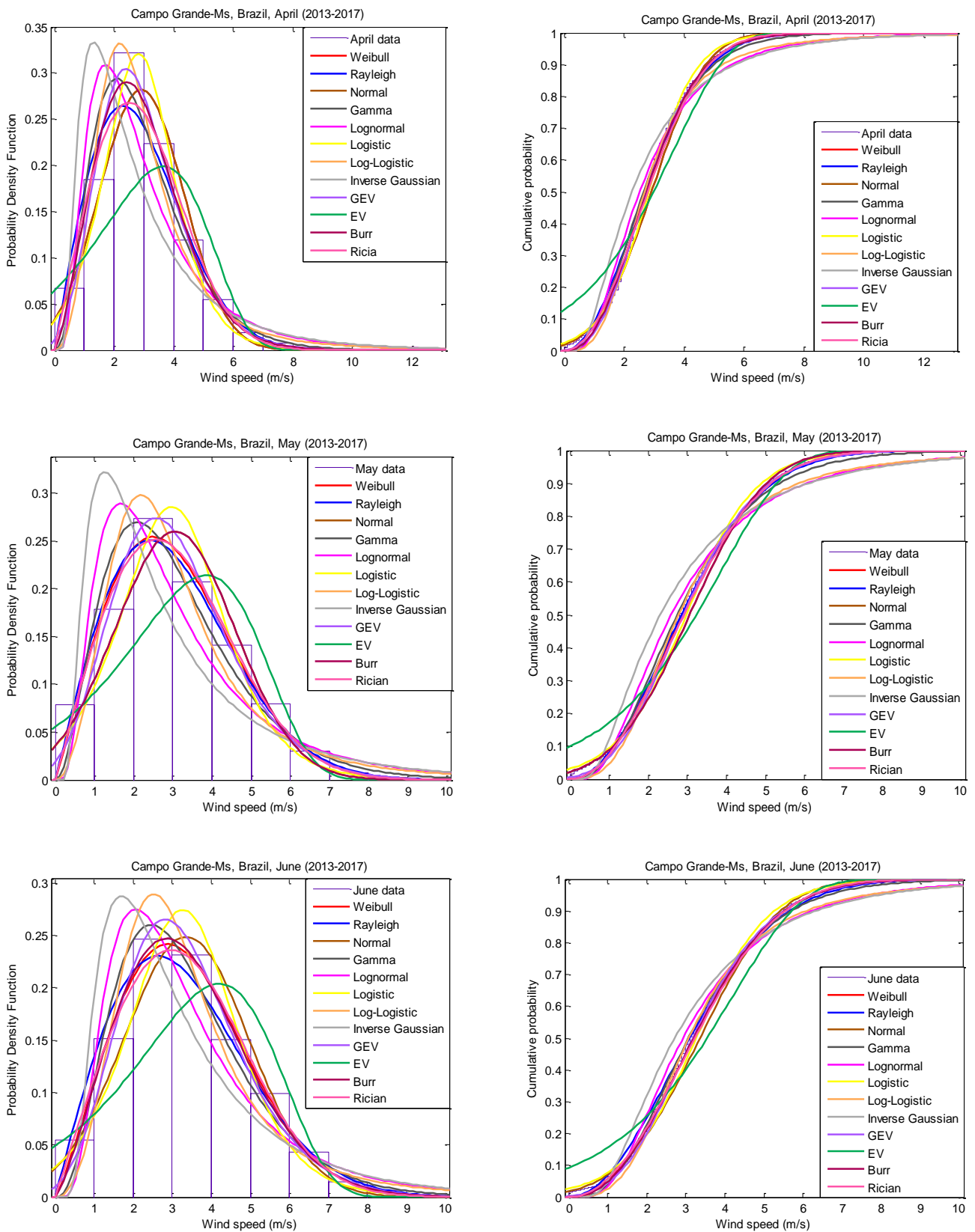

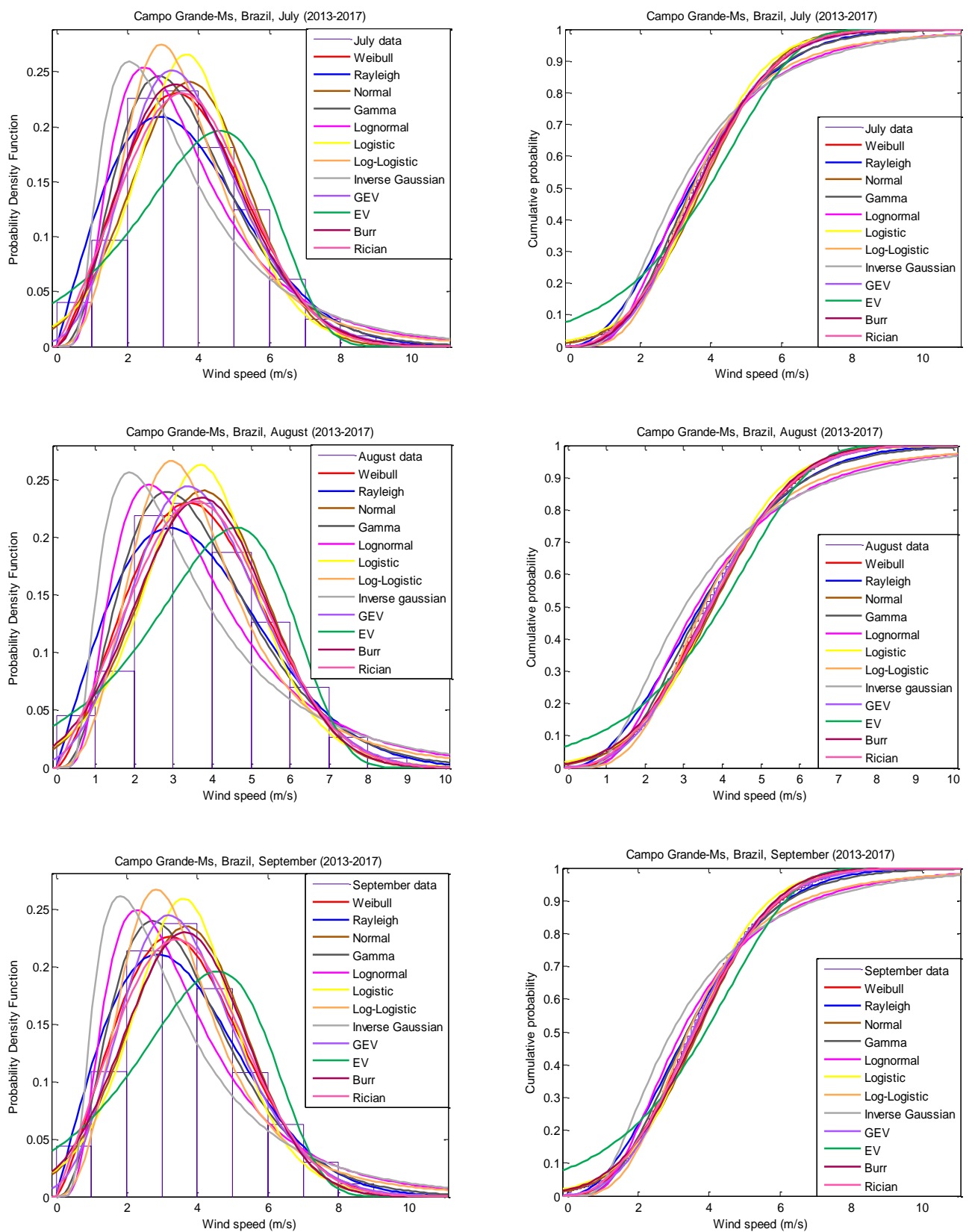

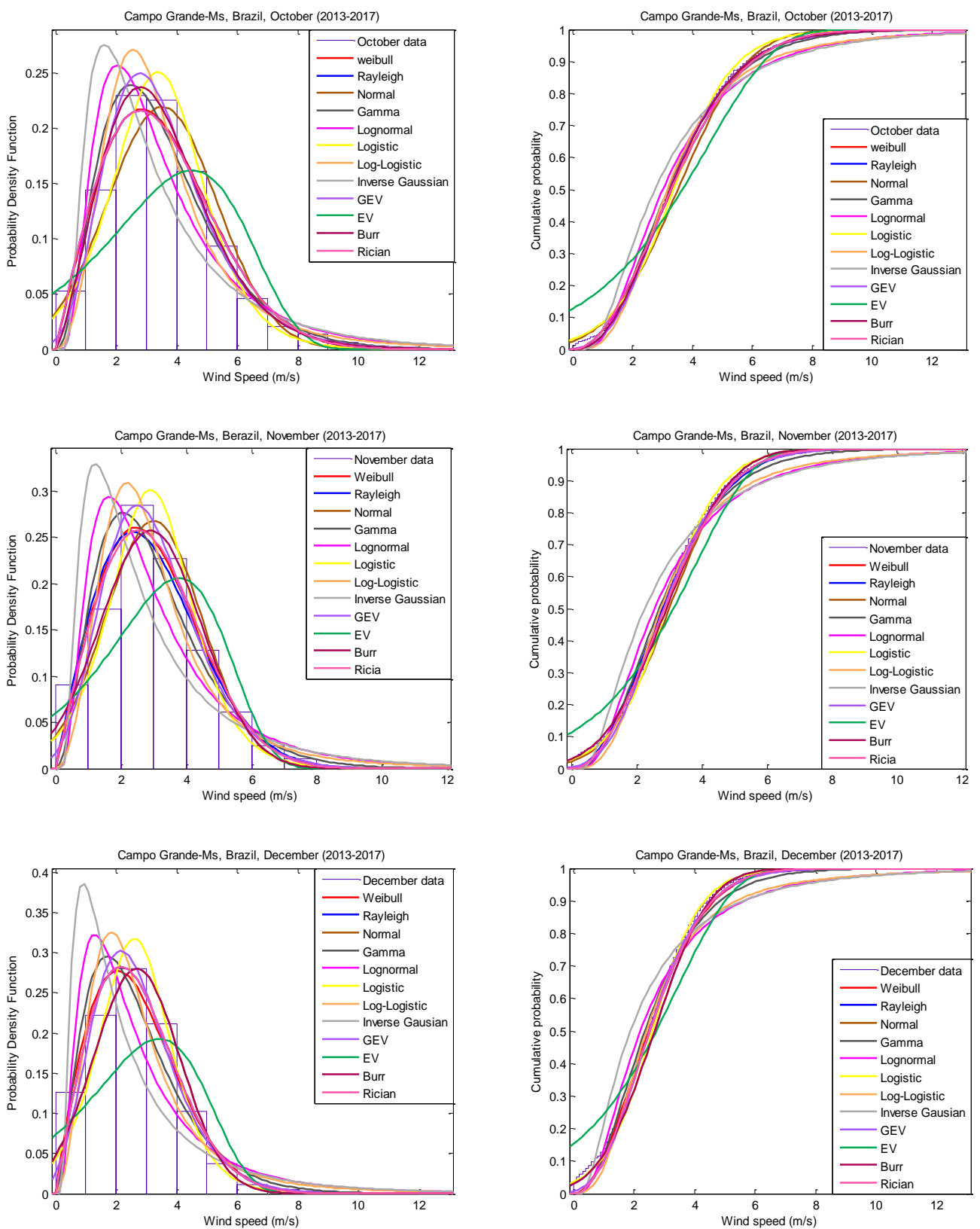

Figure 1 - cdf (left) and pdf (right) graphs of distributions obtained for the monthly averages of wind speeds for the years (2013-2017). 

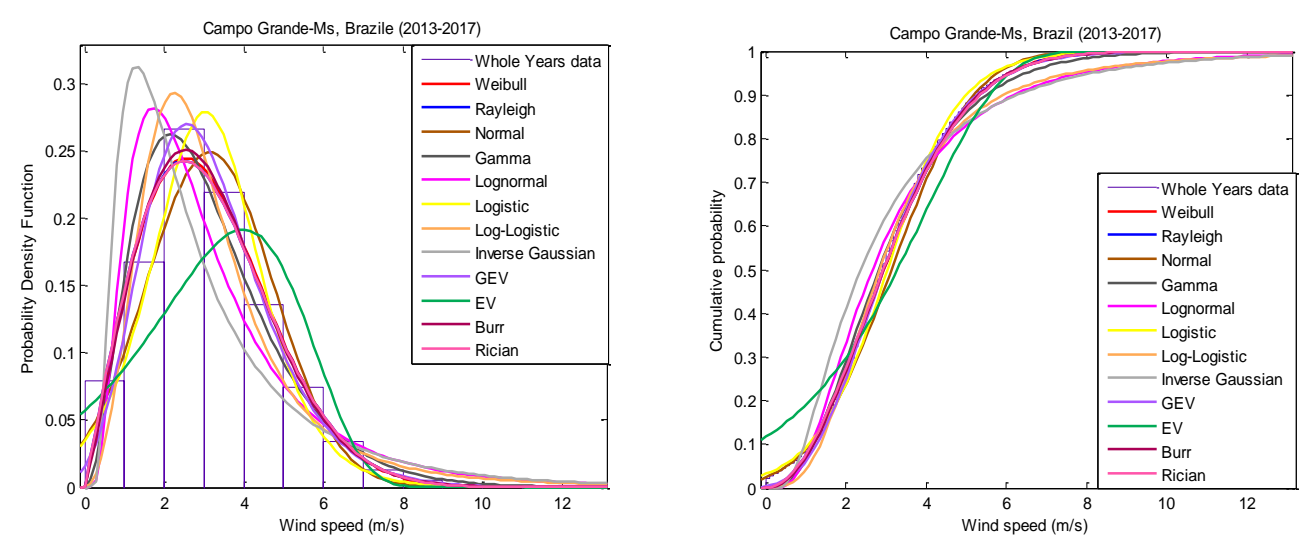

Figure 2 - cdf (left) and PDF (right) charts for the distributions obtained for annual mean wind speeds for the years 2013 to 2017.

\section{ACCURACY TESTS}

In this work, we considered two statistics associated with cdf ( $R^{\wedge} 2$ and RMSE) which are sensitive to the center part of the wind speed distribution and two statistics associated with pdf which are sensitive to the tails of the wind speed distribution [OUARDA, T B M J, CHARRON C, CHEBANA F, 2016].

Table 5 shows the results of the used goodness of-fit tests. Based on $\mathrm{R}^{\wedge} 2$, GEV is clearly the best distribution in ten months, it is followed by RAY which fits better the wind data of two months (Feb and Dec). Based on RMSE, $\mathrm{EV}$ is the best pdf for nine months, $\mathrm{R}$ provides good results for Jan and Nov. LN is the first just for Jul. Based on MAE, EV shows again the best fits for seven months. Others distributions such as W2, RAY, LN and R give also the best fits for the rest of months. Analysis of MAPE reveals that the most preferred distributions are R and G (six months) followed by LN (two months) then by RAY and W2. From this table, it is obvious that EV adjust very good the majority of monthly wind speed distributions. GEV is also recommended basing on $R^{\wedge} 2$. Other distributions such as R, LN and G can also be used as alternatives of the conventional W2 and RAY distributions.

Considering the overall monthly values of every statistic, Figure 3 illustrates the boxplots representing different distributions basing on different criteria. It indicates that the higher values of $R^{\wedge} 2$ are recorded, in this order, by GEV, W2 and R. BR is also accepted (it is ranked fourth). The worst results are obtained by IG, LN, N and EV which present the spread interquartile ranges and low medians (less than 0.9). Evaluation of the RMSE indicates that EV, W2 and $\mathrm{R}$ are superior to other distributions, their median is low than 0.013. Figure 3.b shows that $L$ and $B R$ followed by $L L$ are absolutely rejected by RMSE criterion. According to MAE criterion, EV, W2 and R show by far the best fits with the narrow interquantile gaps and medians low than 0.01. LN and IG show also a small value of the median, but the interquartile gap is more spread. The very poor fits are obtained for $L, B R$ and $L L$. Respecting to MAPE, R, W2, EV and LN are in this order, the most accurate to model the wind speed at the studied region. The very poor distribution is $B R$ followed by $L$. BR presents a median which exceeds $20 \%$ and a very spread interquartile gap. 
Selection of an appropriate model depends mainly on these assessments, which result in very different conclusions from previous research on the subject.

For all four statistics, Table 6 lists the classification of each distribution based on boxplots. Results obtained using MAE, RMSE and MAPE are generally in agreement. We can conclude that the preferred distributions are W2 and R and EV. The last distribution is ranked first by the MAE and RSME and the third by the MAPE. We also note that even if the GEV scores first, it is ranked ninth for other suitability tests. $L L, L$, and $B R$ are rejected, they provide the weakest adjustment based on MAE, RMSE, and MAPE.

A study by ZAHARIM et al., 2009, uses Weibull and lognormal to evaluate wind speed data. Both distributors were checking the suitability test for the parameter performance adjustment. This study found that Weibull is well suited for distribution.

A study of LEITE and VIRGENS FILHO2011 to evaluate the adjustment of hourly average wind speed data for Ponta Grossa, State of Paraná, to the probability distributions of Weibull, Rayleigh, Beta, Gamma and Normal and to analyze possible interferences of the diurnal and adjustment of these models. The Kolmogorov-Smirnov test was used to compare the adjustments and select the best theoretical distributions within each $24 \mathrm{~h}$ of the day in each month of the year. The greater or lesser degree of adjustment of the average hourly wind data to the probabilistic models evaluated was influenced by the time of day, and in the night period the Weibull distribution proved to be the best fit option followed by the Beta and Range distributions .

The most widely used distribution for characterization the average wind speeds is the 2-parameter Weibull distribution (W2) [MANWLL J F, McGOWAN J G, ROGERS A L 2002; BURTON T, SHARPE D, JENKINS N, BOSSANYI E, 1988; HARRIS R I, 2005; HARRIS R I, 2006; RAMIREZ P, CARTA J A, 2005; HENNESSEY J P, 1997; CELIK A N, 2004]. Sometimes the simple 1-parameter Rayleigh (RAY) distribution offers a more concise fit to a sample, since it is a special case of the W2 [MANWELL J F, MCGOWAN J G, ROGERS A L, 2002; CELIK A N, 2004], but ultimately having only a single model parameter makes the RAY much less flexible. Despite the widespread acceptance of the W2 and RAY distributions, CARTA et al. 2011 and others have noted that under different wind regimes other distributions may fit wind samples better. Other distributions used to characterize wind speed include the 3-parameter Generalized Gamma (GG), 2-parameter Gamma (G2), inverse Gaussian, 2-parameter Lognormal (LN2), 3-parameter Beta. Kiss and Janosi 2008, recommend the GG for the ERA-40 dataset (6-hourly mean) after testing the RAY, W2 and LN2 distributions. Simiu et al. 2001 use probability plot correlation coefficient goodness-of-fit tests to document that the RAY distribution provides a poor approximation to hourly wind speeds, but the authors do not advocate an alternative.

Recent studies show that Weibull mixture models out-perform the W2 distribution [JARAMILLO OA, BORJA MA , 2004; AKPINAR S, AKPINAR EK, 2009; CARTA J A, RAMIREZ P, 2007]. However, these studies only use a limited number of samples from confined geographic regions, and often explain the better fits of the mixture models as unique exceptions to the rule. AKPINAR and AKPINAR 2009 show that mixture models out-perform the Weibull distribution and other distributions. CARTA and RAMIREZ 2007 has arrived at similar 
findings for 16 samples in the Canary Islands, as do JARAMILLO and BORJA 2004 for one sample from La Ventosa, Mexico.

Another primary goal of this study is to illustrate that finding an optimal wind speed distributional model is contingent upon the application of interest. Measures of goodness-of-fit commonly used in wind literature (i.e. $R^{\wedge} 2$ ) [CARTA J A, RAMIREZ P, VELAZQUEZ S, 2009; Carta JA, Ramirez P, 2007; CARTA J A, RAMIREZ P, 2007; KISS P, JANOSI I M, 2008; CELIK A N, 2010; CARTA J A, RAMIREZ P, VELAZQUEZ S, 2008] do not necessarily indicate how well a model predicts wind energy parameters. Following CHANG and TU 2009, a model validation approach based on parameter estimation instead of $R^{\wedge} 2$ may find theoretical models that are best suited for specific wind energy applications. In prac- tice, one may resort to a variety of models to give optimal predictions of in situ conditions when lacking observations.

Table 5 - Evaluation of the Performance of the Statistical Distribution for Wind Speed Modeling in Campo Grande and the coefficient values of the statistical functions.

\begin{tabular}{|c|c|c|c|c|c|c|c|c|c|c|c|c|}
\hline $\begin{array}{l}\text { Mon } \\
\text { th }\end{array}$ & Jan & Feb & Mar & Apr & May & Jun & Jul & Aug & Sep & Oct & Nov & Dec \\
\hline \multicolumn{13}{|c|}{ Coefficient of determination } \\
\hline W2 & $\begin{array}{l}0,97 \\
96\end{array}$ & $\begin{array}{l}0,98 \\
88\end{array}$ & $\begin{array}{l}0,97 \\
61\end{array}$ & $\begin{array}{l}0,95 \\
15\end{array}$ & $\begin{array}{l}0,98 \\
65\end{array}$ & $\begin{array}{l}0,99 \\
20\end{array}$ & $\begin{array}{l}0,98 \\
18\end{array}$ & $\begin{array}{l}0,97 \\
40\end{array}$ & $\begin{array}{l}0,98 \\
51\end{array}$ & $\begin{array}{l}0,98 \\
46\end{array}$ & $\begin{array}{l}0,97 \\
42\end{array}$ & $\begin{array}{l}0,98 \\
25\end{array}$ \\
\hline RAY & $\begin{array}{l}0,97 \\
92\end{array}$ & $\begin{array}{l}0,98 \\
93\end{array}$ & $\begin{array}{l}0,97 \\
13\end{array}$ & $\begin{array}{l}0,94 \\
85\end{array}$ & $\begin{array}{l}0,98 \\
25\end{array}$ & $\begin{array}{l}0,97 \\
64\end{array}$ & $\begin{array}{l}0,93 \\
14\end{array}$ & $\begin{array}{l}0,90 \\
88\end{array}$ & $\begin{array}{l}0,94 \\
45\end{array}$ & $\begin{array}{l}0,98 \\
24\end{array}$ & $\begin{array}{l}0,96 \\
73\end{array}$ & $\begin{array}{l}0,98 \\
53\end{array}$ \\
\hline LL & $\begin{array}{l}0,91 \\
47\end{array}$ & $\begin{array}{l}0,91 \\
58\end{array}$ & $\begin{array}{l}0,90 \\
55\end{array}$ & $\begin{array}{l}0,95 \\
36\end{array}$ & $\begin{array}{l}0,93 \\
88\end{array}$ & $\begin{array}{l}0,95 \\
68\end{array}$ & $\begin{array}{l}0,96 \\
11\end{array}$ & $\begin{array}{l}0,94 \\
09\end{array}$ & $\begin{array}{l}0,95 \\
24\end{array}$ & $\begin{array}{l}0,95 \\
76\end{array}$ & $\begin{array}{l}0,92 \\
44\end{array}$ & $\begin{array}{l}0,90 \\
45\end{array}$ \\
\hline IG & $\begin{array}{l}0,70 \\
31\end{array}$ & $\begin{array}{l}0,77 \\
04\end{array}$ & $\begin{array}{l}0,66 \\
46\end{array}$ & $\begin{array}{l}0,67 \\
38\end{array}$ & $\begin{array}{l}0,68 \\
07\end{array}$ & $\begin{array}{l}0,75 \\
67\end{array}$ & $\begin{array}{l}0,72 \\
39\end{array}$ & $\begin{array}{l}0,59 \\
39\end{array}$ & $\begin{array}{l}0,64 \\
63\end{array}$ & $\begin{array}{l}0,70 \\
81\end{array}$ & $\begin{array}{l}0,64 \\
05\end{array}$ & $\begin{array}{l}0,66 \\
23\end{array}$ \\
\hline $\mathrm{N}$ & $\begin{array}{l}0,95 \\
95\end{array}$ & $\begin{array}{l}0,96 \\
36\end{array}$ & $\begin{array}{l}0,97 \\
53\end{array}$ & $\begin{array}{l}0,95 \\
15\end{array}$ & $\begin{array}{l}0,94 \\
98\end{array}$ & $\begin{array}{l}0,95 \\
23\end{array}$ & $\begin{array}{l}0,95 \\
35\end{array}$ & $\begin{array}{l}0,95 \\
95\end{array}$ & $\begin{array}{l}0,96 \\
17\end{array}$ & $\begin{array}{l}0,93 \\
30\end{array}$ & $\begin{array}{l}0,95 \\
83\end{array}$ & $\begin{array}{l}0,96 \\
34\end{array}$ \\
\hline G & $\begin{array}{l}0,93 \\
87\end{array}$ & $\begin{array}{l}0,95 \\
35\end{array}$ & $\begin{array}{l}0,92 \\
38\end{array}$ & $\begin{array}{l}0,94 \\
18\end{array}$ & $\begin{array}{l}0,95 \\
11\end{array}$ & $\begin{array}{l}0,97 \\
09\end{array}$ & $\begin{array}{l}0,96 \\
52\end{array}$ & $\begin{array}{l}0,93 \\
32\end{array}$ & $\begin{array}{l}0,95 \\
15\end{array}$ & $\begin{array}{l}0,96 \\
81\end{array}$ & $\begin{array}{l}0,92 \\
90\end{array}$ & $\begin{array}{l}0,93 \\
78\end{array}$ \\
\hline GEV & $\begin{array}{l}0,98 \\
14\end{array}$ & $\begin{array}{l}0,97 \\
95\end{array}$ & $\begin{array}{l}0,98 \\
21\end{array}$ & $\begin{array}{l}0,98 \\
50\end{array}$ & $\begin{array}{l}0,98 \\
97\end{array}$ & $\begin{array}{l}0,99 \\
48\end{array}$ & $\begin{array}{l}0,99 \\
04\end{array}$ & $\begin{array}{l}0,98 \\
37\end{array}$ & $\begin{array}{l}0,99 \\
57\end{array}$ & $\begin{array}{l}0,99 \\
44\end{array}$ & $\begin{array}{l}0,98 \\
28\end{array}$ & $\begin{array}{l}0,97 \\
74\end{array}$ \\
\hline EV & $\begin{array}{l}0,68 \\
69\end{array}$ & $\begin{array}{l}0,64 \\
94\end{array}$ & $\begin{array}{l}0,73 \\
43\end{array}$ & $\begin{array}{l}0,58 \\
75\end{array}$ & $\begin{array}{l}0,67 \\
97\end{array}$ & $\begin{array}{l}0,66 \\
80\end{array}$ & $\begin{array}{l}0,68 \\
90\end{array}$ & $\begin{array}{l}0,73 \\
90\end{array}$ & $\begin{array}{l}0,67 \\
29\end{array}$ & $\begin{array}{l}0,42 \\
93\end{array}$ & $\begin{array}{l}0,64 \\
38\end{array}$ & $\begin{array}{l}0,54 \\
88\end{array}$ \\
\hline LN & $\begin{array}{l}0,83 \\
26\end{array}$ & $\begin{array}{l}0,86 \\
67\end{array}$ & $\begin{array}{l}0,80 \\
68\end{array}$ & $\begin{array}{l}0,83 \\
28\end{array}$ & $\begin{array}{l}0,83 \\
59\end{array}$ & $\begin{array}{l}0,88 \\
22\end{array}$ & $\begin{array}{l}0,87 \\
95\end{array}$ & $\begin{array}{l}0,80 \\
98\end{array}$ & $\begin{array}{l}0,83 \\
54\end{array}$ & $\begin{array}{l}0,86 \\
64\end{array}$ & $\begin{array}{l}0,80 \\
19\end{array}$ & $\begin{array}{l}0,82 \\
46\end{array}$ \\
\hline L & $\begin{array}{l}0,96 \\
55\end{array}$ & $\begin{array}{l}0,95 \\
92\end{array}$ & $\begin{array}{l}0,97 \\
79\end{array}$ & $\begin{array}{l}0,97 \\
25\end{array}$ & $\begin{array}{l}0,94 \\
64\end{array}$ & $\begin{array}{l}0,95 \\
21\end{array}$ & $\begin{array}{l}0,94 \\
79\end{array}$ & $\begin{array}{l}0,95 \\
04\end{array}$ & $\begin{array}{l}0,96 \\
58\end{array}$ & $\begin{array}{l}0,95 \\
36\end{array}$ & $\begin{array}{l}0,96 \\
79\end{array}$ & $\begin{array}{l}0,95 \\
77\end{array}$ \\
\hline BR & $\begin{array}{l}0,97 \\
96\end{array}$ & $\begin{array}{l}0,98 \\
67\end{array}$ & $\begin{array}{l}0,98 \\
04\end{array}$ & $\begin{array}{l}0,97 \\
68\end{array}$ & $\begin{array}{l}0,94 \\
98\end{array}$ & $\begin{array}{l}0,99 \\
35\end{array}$ & $\begin{array}{l}0,98 \\
54\end{array}$ & $\begin{array}{l}0,96 \\
46\end{array}$ & $\begin{array}{l}0,96 \\
68\end{array}$ & $\begin{array}{l}0,99 \\
36\end{array}$ & $\begin{array}{l}0,96 \\
68\end{array}$ & $\begin{array}{l}0,96 \\
34\end{array}$ \\
\hline $\mathrm{R}$ & $\begin{array}{l}0,98 \\
04\end{array}$ & $\begin{array}{l}0,98 \\
93\end{array}$ & $\begin{array}{l}0,98 \\
15\end{array}$ & $\begin{array}{l}0,96 \\
42\end{array}$ & \begin{tabular}{|l|}
0,98 \\
67
\end{tabular} & $\begin{array}{l}0,98 \\
86\end{array}$ & $\begin{array}{l}0,97 \\
62\end{array}$ & $\begin{array}{l}0,97 \\
31\end{array}$ & $\begin{array}{l}0,98 \\
27\end{array}$ & $\begin{array}{l}0,98 \\
24\end{array}$ & $\begin{array}{l}0,97 \\
58\end{array}$ & $\begin{array}{l}0,98 \\
53\end{array}$ \\
\hline \multicolumn{13}{|c|}{ Root Mean Square Error } \\
\hline
\end{tabular}




\begin{tabular}{|c|c|c|c|c|c|c|c|c|c|c|c|c|}
\hline W2 & $\begin{array}{l}0,01 \\
32\end{array}$ & $\begin{array}{l}0,01 \\
54\end{array}$ & $\begin{array}{l}0,01 \\
12\end{array}$ & $\begin{array}{l}0,01 \\
01\end{array}$ & $\begin{array}{l}0,01 \\
34\end{array}$ & $\begin{array}{l}0,01 \\
14\end{array}$ & $\begin{array}{l}0,00 \\
78\end{array}$ & $\begin{array}{l}0,01 \\
06\end{array}$ & $\begin{array}{l}0,02 \\
32\end{array}$ & $\begin{array}{l}0,01 \\
62\end{array}$ & $\begin{array}{l}0,01 \\
11\end{array}$ & $\begin{array}{l}0,01 \\
45\end{array}$ \\
\hline RAY & $\begin{array}{l}0,01 \\
21\end{array}$ & $\begin{array}{l}0,01 \\
95\end{array}$ & $\begin{array}{l}0,02 \\
18\end{array}$ & $\begin{array}{l}0,01 \\
62\end{array}$ & $\begin{array}{l}0,01 \\
69\end{array}$ & $\begin{array}{l}0,01 \\
82\end{array}$ & $\begin{array}{l}0,01 \\
91\end{array}$ & $\begin{array}{l}0,02 \\
05\end{array}$ & $\begin{array}{l}0,02 \\
32\end{array}$ & $\begin{array}{l}0,01 \\
64\end{array}$ & $\begin{array}{l}0,01 \\
99\end{array}$ & $\begin{array}{l}0,02 \\
04\end{array}$ \\
\hline LL & $\begin{array}{l}0,03 \\
14\end{array}$ & $\begin{array}{l}0,04 \\
29\end{array}$ & $\begin{array}{l}0,03 \\
08\end{array}$ & $\begin{array}{l}0,03 \\
40\end{array}$ & $\begin{array}{l}0,03 \\
67\end{array}$ & $\begin{array}{l}0,02 \\
96\end{array}$ & $\begin{array}{l}0,03 \\
07\end{array}$ & $\begin{array}{l}0,03 \\
76\end{array}$ & $\begin{array}{l}0,04 \\
25\end{array}$ & $\begin{array}{l}0,04 \\
62\end{array}$ & $\begin{array}{l}0,03 \\
85\end{array}$ & $\begin{array}{l}0,04 \\
19\end{array}$ \\
\hline IG & $\begin{array}{l}0,06 \\
04\end{array}$ & $\begin{array}{l}0,01 \\
74\end{array}$ & $\begin{array}{l}0,01 \\
20\end{array}$ & $\begin{array}{l}0,02 \\
02\end{array}$ & $\begin{array}{l}0,02 \\
58\end{array}$ & $\begin{array}{l}0,02 \\
33\end{array}$ & $\begin{array}{l}0,01 \\
40\end{array}$ & $\begin{array}{l}0,01 \\
21\end{array}$ & $\begin{array}{l}0,02 \\
45\end{array}$ & $\begin{array}{l}0,01 \\
78\end{array}$ & $\begin{array}{l}0,01 \\
09\end{array}$ & $\begin{array}{l}0,01 \\
46\end{array}$ \\
\hline $\mathrm{N}$ & $\begin{array}{l}0,01 \\
91\end{array}$ & $\begin{array}{l}0,02 \\
55\end{array}$ & $\begin{array}{l}0,01 \\
48\end{array}$ & $\begin{array}{l}0,01 \\
83\end{array}$ & $\begin{array}{l}0,02 \\
16\end{array}$ & $\begin{array}{l}0,01 \\
58\end{array}$ & $\begin{array}{l}0,01 \\
52\end{array}$ & $\begin{array}{l}0,02 \\
03\end{array}$ & $\begin{array}{l}0,02 \\
51\end{array}$ & $\begin{array}{l}0,02 \\
89\end{array}$ & $\begin{array}{l}0,02 \\
28\end{array}$ & $\begin{array}{l}0,02 \\
53\end{array}$ \\
\hline G & $\begin{array}{l}0,02 \\
49\end{array}$ & $\begin{array}{l}0,01 \\
76\end{array}$ & $\begin{array}{l}0,01 \\
79\end{array}$ & $\begin{array}{l}0,01 \\
58\end{array}$ & $\begin{array}{l}0,01 \\
92\end{array}$ & $\begin{array}{l}0,01 \\
99\end{array}$ & $\begin{array}{l}0,01 \\
97\end{array}$ & $\begin{array}{l}0,02 \\
17\end{array}$ & $\begin{array}{l}0,01 \\
72\end{array}$ & $\begin{array}{l}0,01 \\
60\end{array}$ & $\begin{array}{l}0,02 \\
19\end{array}$ & $\begin{array}{l}0,01 \\
94\end{array}$ \\
\hline GEV & $\begin{array}{l}0,01 \\
53\end{array}$ & $\begin{array}{l}0,02 \\
69\end{array}$ & $\begin{array}{l}0,01 \\
83\end{array}$ & $\begin{array}{l}0,01 \\
92\end{array}$ & $\begin{array}{l}0,02 \\
12\end{array}$ & $\begin{array}{l}0,01 \\
79\end{array}$ & $\begin{array}{l}0,01 \\
96\end{array}$ & $\begin{array}{l}0,02 \\
34\end{array}$ & $\begin{array}{l}0,02 \\
25\end{array}$ & $\begin{array}{l}0,03 \\
26\end{array}$ & $\begin{array}{l}0,03 \\
14\end{array}$ & $\begin{array}{l}0,03 \\
04\end{array}$ \\
\hline EV & $\begin{array}{l}0,06 \\
70\end{array}$ & $\begin{array}{l}0,01 \\
27\end{array}$ & $\begin{array}{l}0,00 \\
65\end{array}$ & $\begin{array}{l}0,00 \\
58\end{array}$ & $\begin{array}{l}0,01 \\
09\end{array}$ & $\begin{array}{l}0,00 \\
87\end{array}$ & $\begin{array}{l}0,00 \\
72\end{array}$ & $\begin{array}{l}0,00 \\
97\end{array}$ & $\begin{array}{l}0,01 \\
28\end{array}$ & $\begin{array}{l}0,01 \\
41\end{array}$ & $\begin{array}{l}0,01 \\
57\end{array}$ & $\begin{array}{l}0,01 \\
42\end{array}$ \\
\hline LN & $\begin{array}{l}0,04 \\
20\end{array}$ & $\begin{array}{l}0,01 \\
79\end{array}$ & $\begin{array}{l}0,00 \\
66\end{array}$ & $\begin{array}{l}0,01 \\
51\end{array}$ & $\begin{array}{l}0,01 \\
57\end{array}$ & $\begin{array}{l}0,01 \\
02\end{array}$ & $\begin{array}{l}0,00 \\
71\end{array}$ & $\begin{array}{l}0,02 \\
05\end{array}$ & $\begin{array}{l}0,01 \\
59\end{array}$ & $\begin{array}{l}0,01 \\
51\end{array}$ & $\begin{array}{l}0,01 \\
23\end{array}$ & $\begin{array}{l}0,01 \\
45\end{array}$ \\
\hline L & $\begin{array}{l}0,02 \\
11\end{array}$ & $\begin{array}{l}0,05 \\
95\end{array}$ & $\begin{array}{l}0,04 \\
69\end{array}$ & $\begin{array}{l}0,05 \\
15\end{array}$ & $\begin{array}{l}0,05 \\
56\end{array}$ & $\begin{array}{l}0,04 \\
56\end{array}$ & $\begin{array}{l}0,04 \\
51\end{array}$ & $\begin{array}{l}0,05 \\
41\end{array}$ & $\begin{array}{l}0,06 \\
03\end{array}$ & $\begin{array}{l}0,06 \\
22\end{array}$ & $\begin{array}{l}0,05 \\
13\end{array}$ & $\begin{array}{l}0,05 \\
71\end{array}$ \\
\hline BR & $\begin{array}{l}0,01 \\
91\end{array}$ & $\begin{array}{l}0,05 \\
71\end{array}$ & $\begin{array}{l}0,06 \\
24\end{array}$ & $\begin{array}{l}0,04 \\
72\end{array}$ & $\begin{array}{l}0,04 \\
26\end{array}$ & $\begin{array}{l}0,04 \\
73\end{array}$ & $\begin{array}{l}0,05 \\
03\end{array}$ & $\begin{array}{l}0,05 \\
18\end{array}$ & $\begin{array}{l}0,06 \\
73\end{array}$ & $\begin{array}{l}0,05 \\
42\end{array}$ & $\begin{array}{l}0,06 \\
18\end{array}$ & $\begin{array}{l}0,05 \\
69\end{array}$ \\
\hline $\mathrm{R}$ & $\begin{array}{l}0,01 \\
21\end{array}$ & $\begin{array}{l}0,01 \\
49\end{array}$ & $\begin{array}{l}0,01 \\
20\end{array}$ & $\begin{array}{l}0,01 \\
09\end{array}$ & $\begin{array}{l}0,01 \\
37\end{array}$ & $\begin{array}{l}0,01 \\
30\end{array}$ & $\begin{array}{l}0,00 \\
94\end{array}$ & $\begin{array}{l}0,01 \\
05\end{array}$ & $\begin{array}{l}0,02 \\
04\end{array}$ & $\begin{array}{l}0,01 \\
42\end{array}$ & $\begin{array}{l}0,01 \\
09\end{array}$ & $\begin{array}{l}0,01 \\
42\end{array}$ \\
\hline \multicolumn{13}{|c|}{ Mean Absolute Error } \\
\hline W2 & $\begin{array}{l}0,00 \\
67\end{array}$ & $\begin{array}{l}0,00 \\
61\end{array}$ & $\begin{array}{l}0,00 \\
90\end{array}$ & $\begin{array}{l}0,00 \\
55\end{array}$ & $\begin{array}{l}0,00 \\
53\end{array}$ & $\begin{array}{l}0,00 \\
48\end{array}$ & $\begin{array}{l}0,00 \\
36\end{array}$ & $\begin{array}{l}0,00 \\
38\end{array}$ & $\begin{array}{l}0,01 \\
45\end{array}$ & $\begin{array}{l}0,00 \\
52\end{array}$ & $\begin{array}{l}0,00 \\
49\end{array}$ & $\begin{array}{l}0,00 \\
50\end{array}$ \\
\hline RAY & $\begin{array}{l}0,00 \\
60\end{array}$ & $\begin{array}{l}0,01 \\
32\end{array}$ & $\begin{array}{l}0,02 \\
10\end{array}$ & $\begin{array}{l}0,01 \\
34\end{array}$ & $\begin{array}{l}0,01 \\
07\end{array}$ & $\begin{array}{l}0,01 \\
29\end{array}$ & $\begin{array}{l}0,01 \\
47\end{array}$ & $\begin{array}{l}0,01 \\
30\end{array}$ & $\begin{array}{l}0,01 \\
45\end{array}$ & $\begin{array}{l}0,01 \\
04\end{array}$ & $\begin{array}{l}0,01 \\
31\end{array}$ & $\begin{array}{l}0,01 \\
29\end{array}$ \\
\hline LL & $\begin{array}{l}0,03 \\
24\end{array}$ & $\begin{array}{l}0,03 \\
92\end{array}$ & $\begin{array}{l}0,03 \\
23\end{array}$ & $\begin{array}{l}0,03 \\
75\end{array}$ & $\begin{array}{l}0,04 \\
09\end{array}$ & $\begin{array}{l}0,03 \\
22\end{array}$ & $\begin{array}{l}0,03 \\
13\end{array}$ & $\begin{array}{l}0,03 \\
68\end{array}$ & $\begin{array}{l}0,03 \\
38\end{array}$ & $\begin{array}{l}0,03 \\
91\end{array}$ & $\begin{array}{l}0,03 \\
14\end{array}$ & $\begin{array}{l}0,03 \\
50\end{array}$ \\
\hline IG & $\begin{array}{l}0,05 \\
92\end{array}$ & $\begin{array}{l}0,00 \\
68\end{array}$ & $\begin{array}{l}0,00 \\
96\end{array}$ & $\begin{array}{l}0,01 \\
63\end{array}$ & $\begin{array}{l}0,02 \\
24\end{array}$ & $\begin{array}{l}0,01 \\
93\end{array}$ & $\begin{array}{l}0,00 \\
93\end{array}$ & $\begin{array}{l}0,00 \\
53\end{array}$ & $\begin{array}{l}0,01 \\
10\end{array}$ & $\begin{array}{l}0,00 \\
60\end{array}$ & $\begin{array}{l}0,00 \\
49\end{array}$ & $\begin{array}{l}0,00 \\
49\end{array}$ \\
\hline $\mathrm{N}$ & $\begin{array}{l}0,01 \\
42\end{array}$ & $\begin{array}{l}0,01 \\
54\end{array}$ & $\begin{array}{l}0,01 \\
05\end{array}$ & $\begin{array}{l}0,01 \\
50\end{array}$ & $\begin{array}{l}0,01 \\
95\end{array}$ & $\begin{array}{l}0,01 \\
32\end{array}$ & $\begin{array}{l}0,01 \\
20\end{array}$ & $\begin{array}{l}0,01 \\
53\end{array}$ & $\begin{array}{l}0,01 \\
21\end{array}$ & $\begin{array}{l}0,01 \\
60\end{array}$ & $\begin{array}{l}0,01 \\
24\end{array}$ & $\begin{array}{l}0,01 \\
36\end{array}$ \\
\hline G & $\begin{array}{l}0,01 \\
57\end{array}$ & $\begin{array}{l}0,01 \\
13\end{array}$ & $\begin{array}{l}0,01 \\
69\end{array}$ & $\begin{array}{l}0,01 \\
32\end{array}$ & $\begin{array}{l}0,01 \\
23\end{array}$ & $\begin{array}{l}0,01 \\
37\end{array}$ & $\begin{array}{l}0,01 \\
40\end{array}$ & $\begin{array}{l}0,01 \\
39\end{array}$ & $\begin{array}{l}0,01 \\
30\end{array}$ & $\begin{array}{l}0,00 \\
83\end{array}$ & $\begin{array}{l}0,01 \\
21\end{array}$ & $\begin{array}{l}0,01 \\
10\end{array}$ \\
\hline GEV & $\begin{array}{l}0,00 \\
66\end{array}$ & $\begin{array}{l}0,02 \\
77\end{array}$ & $\begin{array}{l}0,02 \\
08\end{array}$ & $\begin{array}{l}0,02 \\
37\end{array}$ & $\begin{array}{l}0,02 \\
52\end{array}$ & $\begin{array}{l}0,02 \\
15\end{array}$ & $\begin{array}{l}0,02 \\
28\end{array}$ & $\begin{array}{l}0,02 \\
78\end{array}$ & $\begin{array}{l}0,02 \\
23\end{array}$ & $\begin{array}{l}0,03 \\
08\end{array}$ & $\begin{array}{l}0,02 \\
85\end{array}$ & $\begin{array}{l}0,02 \\
89\end{array}$ \\
\hline EV & $\begin{array}{l}0,04 \\
88\end{array}$ & $\begin{array}{l}0,00 \\
40\end{array}$ & $\begin{array}{l}0,00 \\
37\end{array}$ & $\begin{array}{l}0,00 \\
41\end{array}$ & $\begin{array}{l}0,00 \\
55\end{array}$ & $\begin{array}{l}0,00 \\
40\end{array}$ & $\begin{array}{l}0,00 \\
44\end{array}$ & $\begin{array}{l}0,00 \\
48\end{array}$ & $\begin{array}{l}0,00 \\
36\end{array}$ & $\begin{array}{l}0,00 \\
49\end{array}$ & $\begin{array}{l}0,00 \\
56\end{array}$ & $\begin{array}{l}0,00 \\
40\end{array}$ \\
\hline
\end{tabular}




\begin{tabular}{|c|c|c|c|c|c|c|c|c|c|c|c|c|}
\hline LN & $\begin{array}{l}0,04 \\
17\end{array}$ & $\begin{array}{l}0,01 \\
29\end{array}$ & $\begin{array}{l}0,00 \\
40\end{array}$ & $\begin{array}{l}0,01 \\
30\end{array}$ & $\begin{array}{l}0,01 \\
06\end{array}$ & $\begin{array}{l}0,00 \\
42\end{array}$ & $\begin{array}{l}0,00 \\
30\end{array}$ & $\begin{array}{l}0,01 \\
30\end{array}$ & $\begin{array}{l}0,00 \\
44\end{array}$ & $\begin{array}{l}0,00 \\
96\end{array}$ & $\begin{array}{l}0,00 \\
47\end{array}$ & $\begin{array}{l}0,00 \\
50\end{array}$ \\
\hline L & $\begin{array}{l}0,01 \\
17\end{array}$ & $\begin{array}{l}0,05 \\
31\end{array}$ & $\begin{array}{l}0,04 \\
66\end{array}$ & $\begin{array}{l}0,05 \\
19\end{array}$ & $\begin{array}{l}0,05 \\
78\end{array}$ & $\begin{array}{l}0,04 \\
63\end{array}$ & $\begin{array}{l}0,04 \\
23\end{array}$ & $\begin{array}{l}0,05 \\
45\end{array}$ & $\begin{array}{l}0,04 \\
97\end{array}$ & $\begin{array}{l}0,05 \\
49\end{array}$ & $\begin{array}{l}0,04 \\
49\end{array}$ & $\begin{array}{l}0,05 \\
05\end{array}$ \\
\hline BR & $\begin{array}{l}0,01 \\
42\end{array}$ & $\begin{array}{l}0,04 \\
46\end{array}$ & $\begin{array}{l}0,06 \\
08\end{array}$ & $\begin{array}{l}0,04 \\
23\end{array}$ & $\begin{array}{l}0,03 \\
64\end{array}$ & $\begin{array}{l}0,04 \\
36\end{array}$ & $\begin{array}{l}0,04 \\
17\end{array}$ & $\begin{array}{l}0,03 \\
85\end{array}$ & $\begin{array}{l}0,05 \\
29\end{array}$ & $\begin{array}{l}0,03 \\
45\end{array}$ & $\begin{array}{l}0,03 \\
91\end{array}$ & $\begin{array}{l}0,03 \\
58\end{array}$ \\
\hline $\mathrm{R}$ & $\begin{array}{l}0,00 \\
60\end{array}$ & $\begin{array}{l}0,00 \\
69\end{array}$ & $\begin{array}{l}0,00 \\
96\end{array}$ & $\begin{array}{l}0,00 \\
61\end{array}$ & $\begin{array}{l}0,00 \\
62\end{array}$ & $\begin{array}{l}0,00 \\
69\end{array}$ & $\begin{array}{l}0,00 \\
49\end{array}$ & $\begin{array}{l}0,00 \\
36\end{array}$ & $\begin{array}{l}0,00 \\
94\end{array}$ & $\begin{array}{l}0,00 \\
57\end{array}$ & $\begin{array}{l}0,00 \\
49\end{array}$ & $\begin{array}{l}0,00 \\
53\end{array}$ \\
\hline \multicolumn{13}{|c|}{ Mean absolute percentage error (\%) } \\
\hline W2 & $\begin{array}{l}1,97 \\
06\end{array}$ & $\begin{array}{l}2,77 \\
54\end{array}$ & $\begin{array}{l}3,21 \\
48\end{array}$ & $\begin{array}{l}3,20 \\
81\end{array}$ & $\begin{array}{l}5,27 \\
71\end{array}$ & $\begin{array}{l}3,83 \\
27\end{array}$ & $\begin{array}{l}1,43 \\
31\end{array}$ & $\begin{array}{l}1,53 \\
82\end{array}$ & $\begin{array}{l}4,90 \\
68\end{array}$ & $\begin{array}{l}2,04 \\
17\end{array}$ & $\begin{array}{l}1,69 \\
98\end{array}$ & $\begin{array}{l}2,06 \\
34\end{array}$ \\
\hline RAY & $\begin{array}{l}2,40 \\
32\end{array}$ & $\begin{array}{l}2,07 \\
47\end{array}$ & $\begin{array}{l}8,24 \\
43\end{array}$ & $\begin{array}{l}5,05 \\
56\end{array}$ & $\begin{array}{l}3,02 \\
73\end{array}$ & $\begin{array}{l}4,71 \\
16\end{array}$ & $\begin{array}{l}5,14 \\
08\end{array}$ & $\begin{array}{l}3,29 \\
70\end{array}$ & $\begin{array}{l}4,90 \\
68\end{array}$ & $\begin{array}{l}1,74 \\
07\end{array}$ & $\begin{array}{l}2,50 \\
13\end{array}$ & $\begin{array}{l}2,36 \\
42\end{array}$ \\
\hline LL & $\begin{array}{l}7,37 \\
39\end{array}$ & $\begin{array}{l}8,63 \\
56\end{array}$ & $\begin{array}{l}9,69 \\
34\end{array}$ & $\begin{array}{l}13,5 \\
08\end{array}$ & $\begin{array}{l}16,0 \\
96\end{array}$ & $\begin{array}{l}13,6 \\
70\end{array}$ & $\begin{array}{l}9,96 \\
90\end{array}$ & $\begin{array}{l}7,63 \\
10\end{array}$ & $\begin{array}{l}7,56 \\
56\end{array}$ & $\begin{array}{l}7,60 \\
56\end{array}$ & $\begin{array}{l}5,13 \\
23\end{array}$ & $\begin{array}{l}6,12 \\
95\end{array}$ \\
\hline IG & $\begin{array}{l}16,8 \\
05\end{array}$ & $\begin{array}{l}2,37 \\
81\end{array}$ & $\begin{array}{l}3,91 \\
73\end{array}$ & $\begin{array}{l}9,54 \\
60\end{array}$ & $\begin{array}{l}11,8 \\
09\end{array}$ & $\begin{array}{l}12,1 \\
47\end{array}$ & $\begin{array}{l}5,58 \\
30\end{array}$ & $\begin{array}{l}1,89 \\
25\end{array}$ & $\begin{array}{l}6,58 \\
36\end{array}$ & $\begin{array}{l}1,79 \\
31\end{array}$ & $\begin{array}{l}1,91 \\
07\end{array}$ & $\begin{array}{l}2,00 \\
23\end{array}$ \\
\hline $\mathrm{N}$ & $\begin{array}{l}2,58 \\
54\end{array}$ & $\begin{array}{l}5,30 \\
18\end{array}$ & $\begin{array}{l}4,55 \\
71\end{array}$ & $\begin{array}{l}7,85 \\
54\end{array}$ & $\begin{array}{l}10,4 \\
13\end{array}$ & $\begin{array}{l}8,34 \\
19\end{array}$ & $\begin{array}{l}5,42 \\
71\end{array}$ & $\begin{array}{l}4,41 \\
37\end{array}$ & $\begin{array}{l}3,76 \\
62\end{array}$ & $\begin{array}{l}3,96 \\
33\end{array}$ & $\begin{array}{l}3,19 \\
92\end{array}$ & $\begin{array}{l}3,76 \\
38\end{array}$ \\
\hline G & $\begin{array}{l}3,52 \\
21\end{array}$ & $\begin{array}{l}1,61 \\
26\end{array}$ & $\begin{array}{l}7,50 \\
06\end{array}$ & $\begin{array}{l}6,11 \\
89\end{array}$ & $\begin{array}{l}4,70 \\
75\end{array}$ & $\begin{array}{l}6,27 \\
47\end{array}$ & $\begin{array}{l}5,75 \\
64\end{array}$ & $\begin{array}{l}3,67 \\
87\end{array}$ & $\begin{array}{l}4,47 \\
90\end{array}$ & $\begin{array}{l}1,28 \\
33\end{array}$ & $\begin{array}{l}2,19 \\
77\end{array}$ & $\begin{array}{l}1,75 \\
51\end{array}$ \\
\hline GEV & $\begin{array}{l}2,71 \\
58\end{array}$ & $\begin{array}{l}8,32 \\
20\end{array}$ & $\begin{array}{l}7,62 \\
17\end{array}$ & $\begin{array}{l}9,74 \\
70\end{array}$ & $\begin{array}{l}10,4 \\
90\end{array}$ & $\begin{array}{l}10,3 \\
18\end{array}$ & $\begin{array}{l}8,23 \\
62\end{array}$ & $\begin{array}{l}7,61 \\
62\end{array}$ & $\begin{array}{l}7,28 \\
74\end{array}$ & $\begin{array}{l}7,66 \\
20\end{array}$ & $\begin{array}{l}6,77 \\
49\end{array}$ & $\begin{array}{l}7,36 \\
11\end{array}$ \\
\hline EV & $\begin{array}{l}13,2 \\
89\end{array}$ & $\begin{array}{l}3,00 \\
74\end{array}$ & $\begin{array}{l}2,41 \\
28\end{array}$ & $\begin{array}{l}2,69 \\
97\end{array}$ & $\begin{array}{l}4,29 \\
66\end{array}$ & $\begin{array}{l}3,91 \\
17\end{array}$ & $\begin{array}{l}2,59 \\
91\end{array}$ & $\begin{array}{l}1,88 \\
42\end{array}$ & $\begin{array}{l}2,18 \\
72\end{array}$ & $\begin{array}{l}2,47 \\
65\end{array}$ & $\begin{array}{l}2,63 \\
35\end{array}$ & $\begin{array}{l}2,50 \\
12\end{array}$ \\
\hline LN & $\begin{array}{l}7,68 \\
08\end{array}$ & $\begin{array}{l}3,65 \\
08\end{array}$ & $\begin{array}{l}2,21 \\
74\end{array}$ & $\begin{array}{l}6,83 \\
22\end{array}$ & $\begin{array}{l}5,13 \\
06\end{array}$ & $\begin{array}{l}4,28 \\
81\end{array}$ & $\begin{array}{l}1,74 \\
73\end{array}$ & $\begin{array}{l}3,29 \\
70\end{array}$ & $\begin{array}{l}1,78 \\
10\end{array}$ & $\begin{array}{l}2,20 \\
11\end{array}$ & $\begin{array}{l}1,97 \\
85\end{array}$ & $\begin{array}{l}2,07 \\
12\end{array}$ \\
\hline L & $\begin{array}{l}2,29 \\
80\end{array}$ & $\begin{array}{l}15,8 \\
54\end{array}$ & $\begin{array}{l}14,0 \\
18\end{array}$ & $\begin{array}{l}16,1 \\
87\end{array}$ & $\begin{array}{l}20,6 \\
39\end{array}$ & $\begin{array}{l}17,5 \\
56\end{array}$ & $\begin{array}{l}10,8 \\
48\end{array}$ & $\begin{array}{l}16,8 \\
39\end{array}$ & $\begin{array}{l}18,2 \\
89\end{array}$ & $\begin{array}{l}16,2 \\
02\end{array}$ & $\begin{array}{l}11,4 \\
35\end{array}$ & $\begin{array}{l}14,0 \\
89\end{array}$ \\
\hline BR & $\begin{array}{l}2,58 \\
54\end{array}$ & $\begin{array}{l}16,0 \\
65\end{array}$ & $\begin{array}{l}34,7 \\
15\end{array}$ & $\begin{array}{l}29,1 \\
93\end{array}$ & $\begin{array}{l}24,9 \\
80\end{array}$ & $\begin{array}{l}33,0 \\
93\end{array}$ & $\begin{array}{l}24,1 \\
95\end{array}$ & $\begin{array}{l}15,9 \\
53\end{array}$ & $\begin{array}{l}28,0 \\
36\end{array}$ & $\begin{array}{l}10,4 \\
20\end{array}$ & $\begin{array}{l}9,82 \\
39\end{array}$ & $\begin{array}{l}9,92 \\
51\end{array}$ \\
\hline $\mathrm{R}$ & $\begin{array}{l}2,22 \\
65\end{array}$ & $\begin{array}{l}2,66 \\
11\end{array}$ & $\begin{array}{l}4,18 \\
00\end{array}$ & $\begin{array}{l}1,88 \\
85\end{array}$ & $\begin{array}{l}6,82 \\
15\end{array}$ & $\begin{array}{l}3,76 \\
37\end{array}$ & $\begin{array}{l}2,03 \\
78\end{array}$ & $\begin{array}{l}1,20 \\
86\end{array}$ & $\begin{array}{l}3,72 \\
04\end{array}$ & $\begin{array}{l}1,88 \\
25\end{array}$ & $\begin{array}{l}1,87 \\
47\end{array}$ & $\begin{array}{l}1,99 \\
65\end{array}$ \\
\hline
\end{tabular}

bold values, the best setting values for functions 
(a)

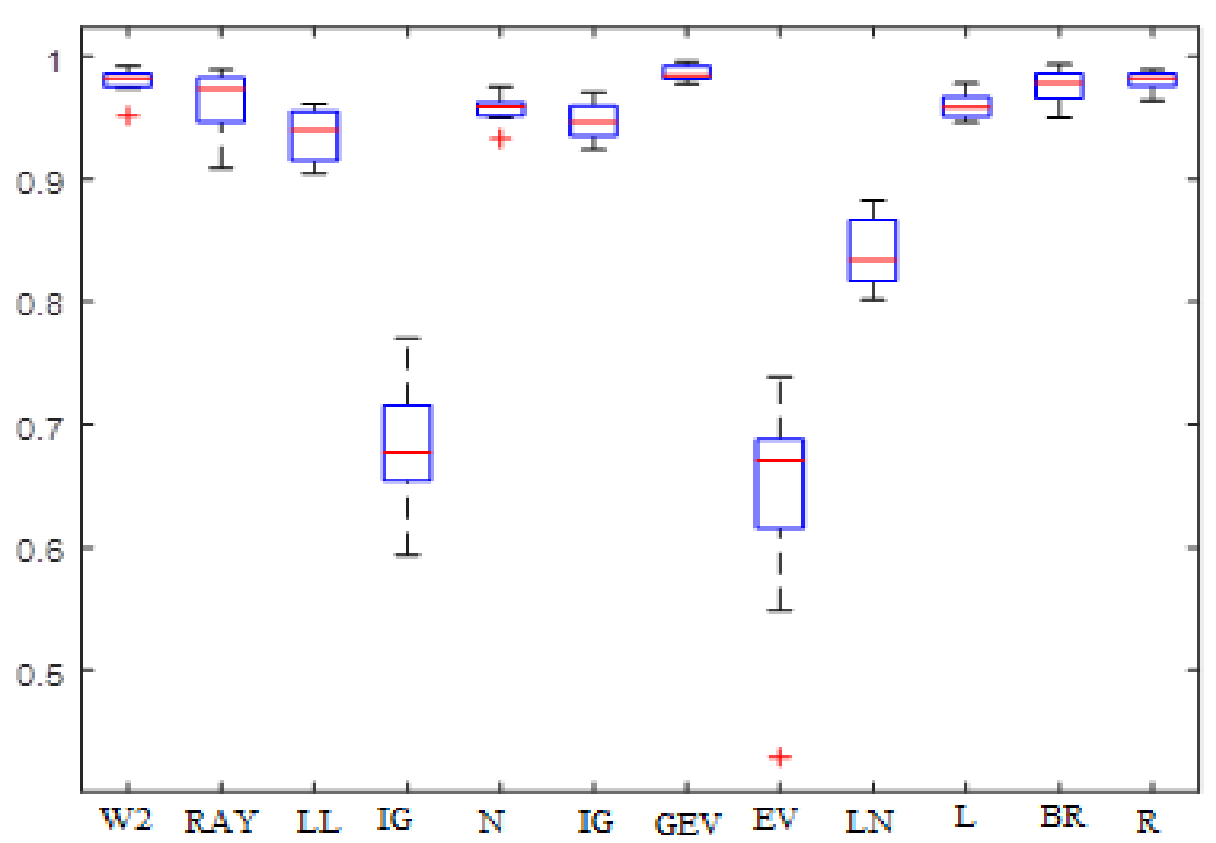

(b)

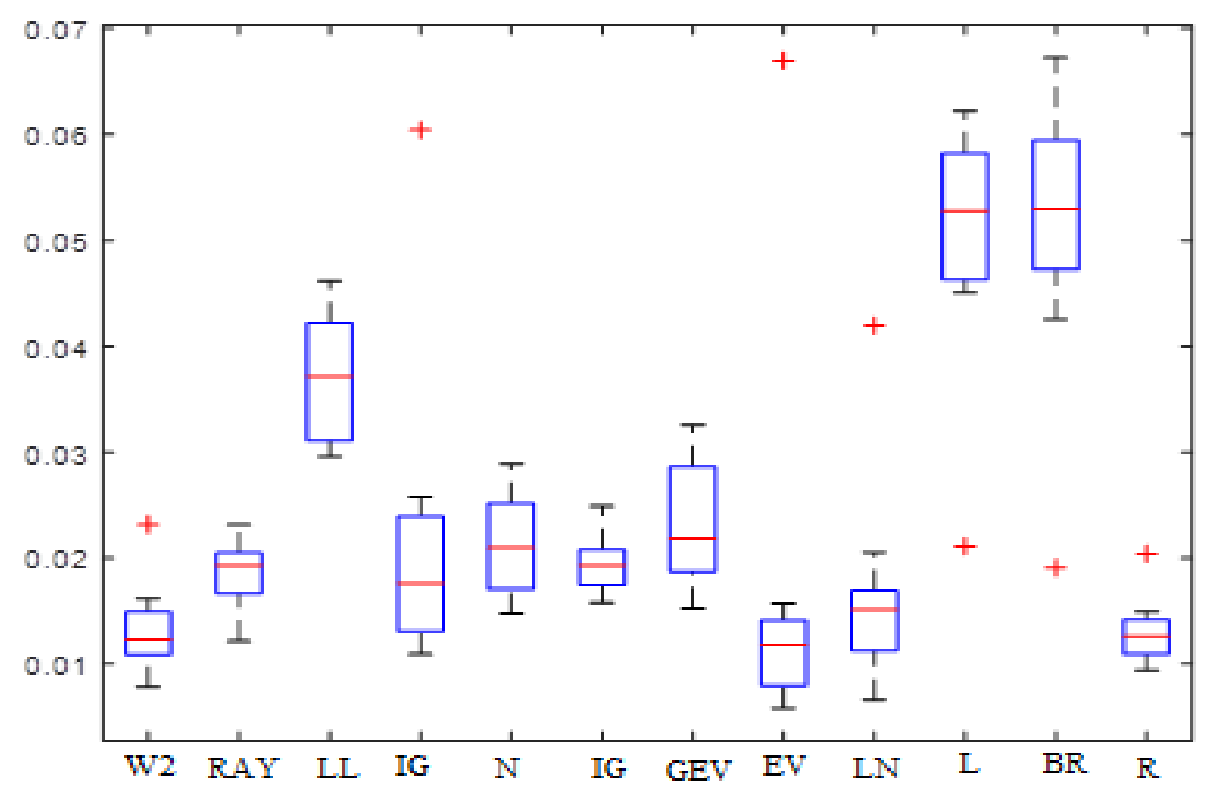


(c)

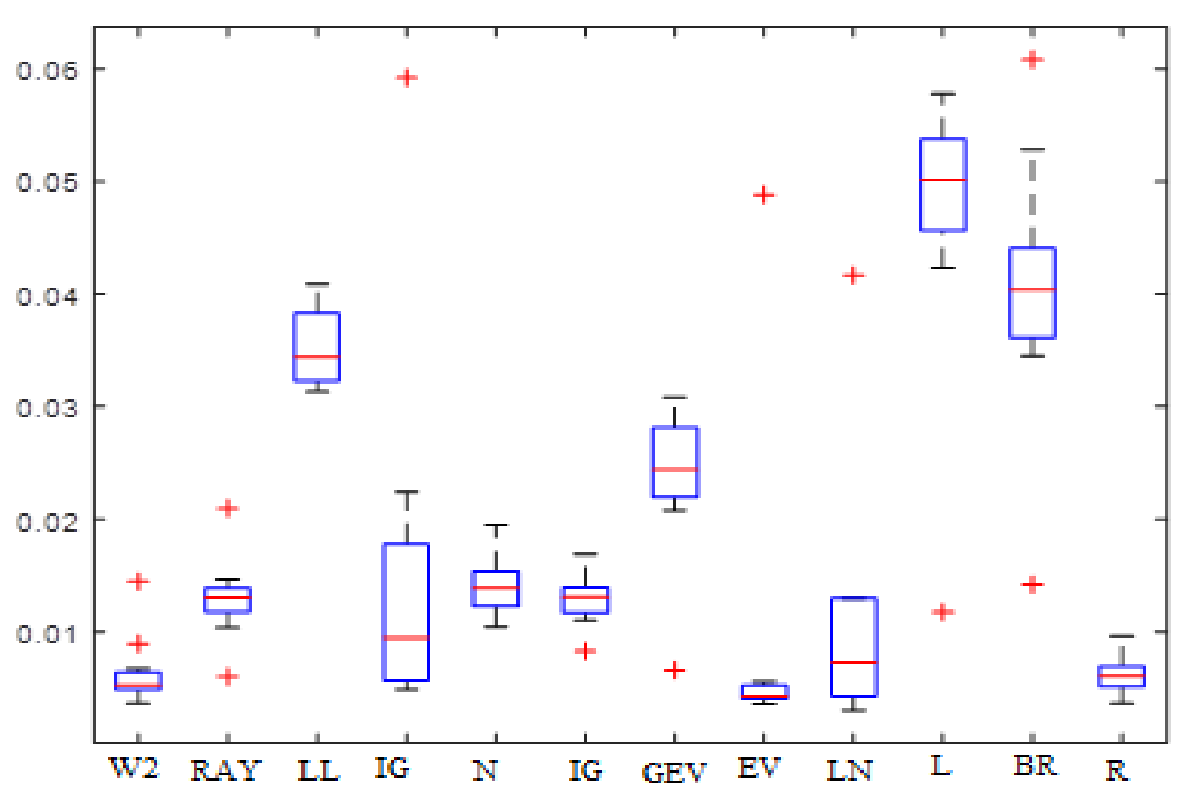

(d)

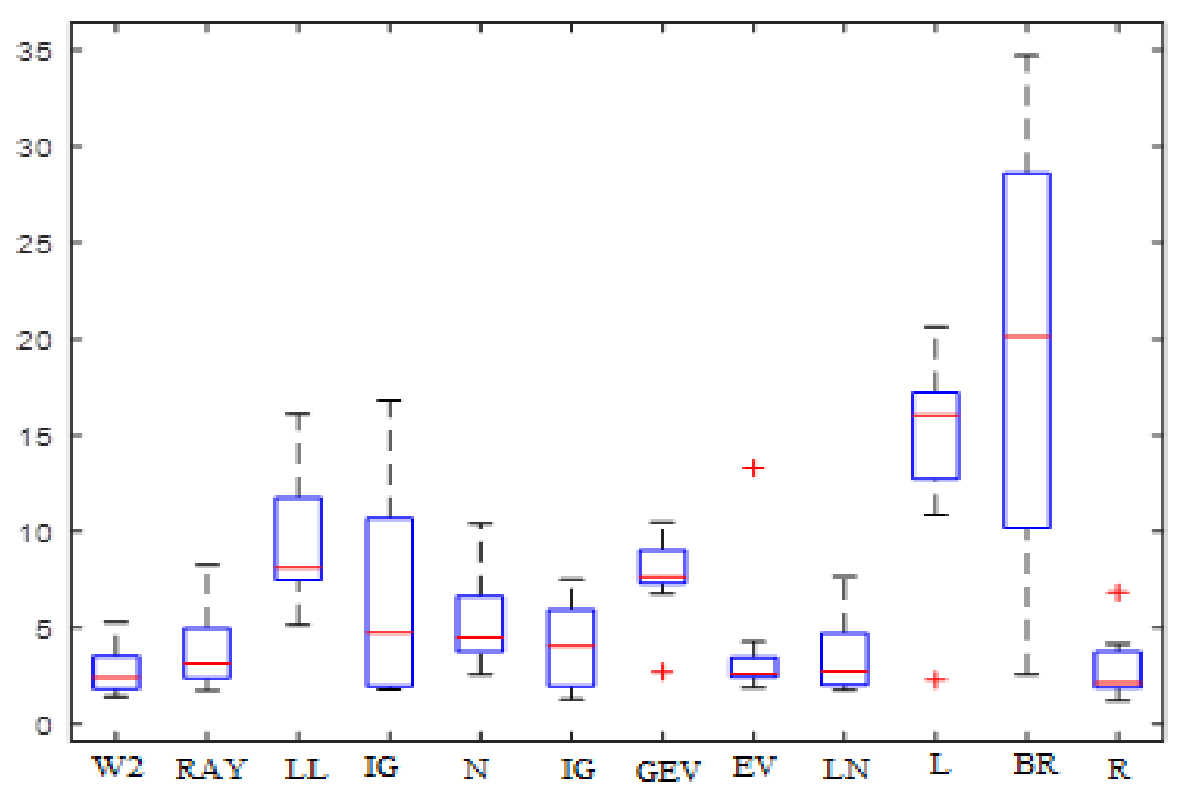

Figure 3 - Boxplots of accuracy tests: (a) R^2, (b) RMSE, (c) MAE and (d) MAPE. 
Table 6- Rank of the studied distribution according to $\mathrm{R}^{\wedge} 2$, RMSE, MAE and MAPE.

\begin{tabular}{|l|l|l|l|l|}
\hline Rank & $\mathrm{R}^{2}$ & RMSE & MAE & MAPE \\
\hline 1 & GEV & EV & EV & R \\
\hline 2 & W2 & W2 & W2 & W2 \\
\hline 3 & R & R & R & EV \\
\hline 4 & BR & LN & LN & LN \\
\hline 5 & RAY & IG & IG & RAY \\
\hline 6 & N & G & RAY & G \\
\hline 7 & L & RAY & G & N \\
\hline 8 & G & N & N & IG \\
\hline 9 & LL & GEV & GEV & GEV \\
\hline 10 & LN & LL & LL & LL \\
\hline 11 & IG & L & BR & L \\
\hline 12 & EV & BR & L & BR \\
\hline
\end{tabular}

\section{CONCLUSION}

Analysis of the monthly values of $R^{\wedge} 2$ indicates that GEV is the best distribution, it is ranked first in ten months. It is followed by RAY. Based on RMSE, EV provides the best results. $\mathrm{R}$ and $\mathrm{LN}$ are also good alternatives. According to MAE, EV shows again the best fits. Other distributions such as W2, RAY, LN and $R$ give also good results. MAPE reveals that the most preferred distributions are $R$ and $G$ followed by $L N$ then by RAY and $W 2$.

The boxplots representing different distributions for each criterion indicate that the higher values of $R^{\wedge} 2$ are recorded, in this order, by GEV, W2 and R. while the worst results are obtained by IG, LN, N and EV. Evaluation of the RMSE reveals that EV, W2 and R are superior to other distributions. This criterion rejects absolutely $L$ and $B R$ followed by $L L$. In regards to $M A E, E V, W 2$ and $R$ show by far the best fits. The very poor fits are obtained for $L, B R$ and $L L$. Respect to MAPE, R, W2, EV and LN are in this order, the most accurate to model the wind speed at the studied region. The very poor distribution is $B R$ followed by L. BR.

Based on the obtained results, the conclusion that we can drew is that Weibull, Rayleigh, Generalized extreme value, Extreme value and Rician distributions perform accurately the data. These distributions can be used as an alternative distribution that adequately describes the considered wind speed data in Campo Grande unlike Normal, Burr, Logistic, log-Logistic, Inverse Gaussian distributions which show the poorest fits.

\section{REFERENCES}

AKPINAR S, AKPINAR E K. Estimation of wind energy potential using finite mixture distribution models. Energy Convers Manage; 50(4): 877-884, 2009. 
AKPINAR E K, AKPINAR S. A statistical analysis of wind speed data used in installation of wind energy conversion systems. Energy Convers Manage;46(4):515-532, 2005.

AUWERA L, MEYER F, MALET L. The use of the Weibull three-parameter model for estimating mean power densities. J Appl Meteorol; 19:819-825, 1980.

AYODELE T R, JIMOH A A, MUNDA J L, AGEE J T. Wind distribution and capacity factor estimation for wind turbines in the coastal region of South Africa. Energy Convers Manage; 64:614-625, 2012. (Africa do Sul)

BURTON T, SHARPE D, JENKINS N, BOSSANYI E. Wind energy handbook. 1st ed. John Wiley \& Sons Ltd 2001.

CARTA J A, RAMIREZ $P$. Use of finite mixture distribution models in the analysis of wind energy in the Canarian Archipelago. Energy Convers Manage; 48(1):281-291, 2007.

CARTA J A, RAMIREZ P. Analysis of two-component mixture Weibull statistics for estimation of wind speed distributions. Renew Energy; 32(3):518-531, 2007.

CARTA J A, RAMIREZ P, VELAZQUEZ S. Influence of the level of fit of a probability density function to wind-speed data on the WECS mean power output estimation. Energy Convers Manage; 49(10):2647-2655, 2008.

CARTA J A, RAMIREZ P, VELAZQUEZ S. A review of wind speed probability distributions used in wind energy analysis Case studies in the Canary Islands. Renew Sustain Energy Rev; 13(5):933-955, 2009.

CELIK AN. Energy output estimation for small-scale wind power generators using Weibull-representative wind data. J Wind Eng Ind Aerodyn; 91(5):693707, 2003.

CELIK A N. A statistical analysis of wind power density based on the Weibull and Rayleigh models at the southern region of Turkey. Renew Energy; 29(4):593604, 2004.

CELIK A N. On the distributional parameters used in assessment of the suitability of wind speed probability density functions. Energy Convers Manage; 45(11-12):1735-1747, 2004.

CHANG T-J, Tu Y-L. Evaluation of monthly capacity factor of WECS using chronological and probabilistic wind speed data: a case study of Taiwan. Renew Energy; 32(12):1999-2010, 2007.

CHANG T P. Estimation of wind energy potential using different probability density functions. Appl Energy; 88(5):1848-1856, 2011.

HARRIS R I. Generalised pareto methods for wind extremes. useful tool or mathematical mirage? J Wind Eng Ind Aerodyn; 93(5):341-360, 2005

HARRIS R I. Errors in gev analysis of wind epoch maxima from Weibull parents. Wind Struct;9(3):179-191, 2006.

HENNESSEY J P. Some aspects of wind power statistics. J Appl Meteorol; 16(2):119-128, 1977.

HU Q, WANG Y, XIE Z, ZHU P, YU D. On estimating uncertainty of wind energy with mixture of distributions. Energy; 112:935-962, 2016. 
IRWANTO M, GOMESH N, MAMAT M R, YUSOFF Y M. Assessment of wind power generation potential in Perlis, Malaysia. Renew Sustain Energy Rev; 38:296308, 2014.

JARAMILLO O A, SALDAÑA R, MIRANDA $U$. Wind power potential of Baja California Sur, México. Renew Energy; 29(13):2087-2100, 2004.

JUSTUS CG, Hargraves WR, Mikhail A, Graber D. Methods for estimating wind speed frequency distributions. J Appl Meteorol; 17(3):350-353, 1978.

KISS P, JANOSI I M. Comprehensive empirical analysis of ERA-40 surface wind speed distribution over Europe. Energy Convers Manage; 49(8):2142-2151, 2008.

KOSE R, OZGUR M A, ERBAS O, TUGCU A. The analysis of wind data and wind energy potential in Kutahya, Turkey. Renew Sustain Energy Rev; 8(3):277-288, 2004.

LEITE M L, VIRGENS FILHO, J S. Adjustment of probability distribution models to hourly wind speed series for the municipality of Ponta Grossa, State of Parana. Acta Scientiarum: Technology; 33(4):447-455, 2011.

Li M, Li X. MEP-type distribution function: a better alternative to Weibull function for wind speed distributions. Renew Energy; 30(8):1221-1240, 2005.

MANWELL J F, MCGOWAN J G, ROGERS A L. Wind energy explained: theory, design and application. 1st ed. John Wiley \& Sons, Inc.: Chichester, UK, 2002.

MIRHOSSEINI M, SHARIFI F, SEDAGHAT A. Assessing the wind energy potential locations in province of Semnan in Iran. Renew Sustain Energy Rev; 15(1):449459, 2011.

MOHAMMADI K, ALAVI O, MCGOWAN J G. Use of Birnbaum-Saunders distribution for estimating wind speed and wind power probability distributions: A review. Energy Convers. Manag.; 143:109-122, 2017.

MORGAN E C, LACKNER M, VOGEL R M, BAISE L G. Probability distributions for offshore wind speeds. Energy Convers Manage; 52(1):15-26, 2011.

ORDÓÑEZ G, OSMA G, VERGARA P, REY J. Wind and solar energy potential assessment for development of renewables energies applications in Bucaramanga, Colombia. IOP conference series: materials science and engineering;, 59(1), 2014

QUARDA, T B M J, CHARRON C, CHEBANA F. Review of criteria for the selection of probability distributions for wind speed data and introduction of the moment and L-moment ratio diagram methods, with a case study. Energy Conversion and Management; 124:247-265, 2016.

RAMIREZ P, CARTA J A. Influence of the data sampling interval in the estimation of the parameters of the Weibull wind speed probability density distribution: a case study. Energy Convers Manage; 46(15-16):2419-2438, 2005.

SEGURO J V, LAMBERT T W. Modern estimation of the parameters of the Weibull wind speed distribution for wind energy analysis. J Wind Eng Ind Aerodyn; 85(1):75-84, 2000 
SIMIU E, HECKERT N, FILLIBEN J, JOHNSON S. Extreme wind load estimates based on the Gumbel distribution of dynamic pressures: an assessment. Struct Safety; 23(3):221-229, 2001.

TIZGUI I, EL GUEZAR F, BOUZAHIR H, BENAID B. Comparison of Methods in Estimating Weibull Parameters for Wind Energy Applications. International Journal of Energy Sector Management; 11(4): 650-663, 2017.

TULLER S E, BRETT A C. The goodness of fit of the Weilbull and Rayleigh distribution to the distributions of observed wind speeds in a topographically diverse area. International Journal of Climatology; 5(1):74-94, 1985.

WU J, WANG JZ, CHI DZ. Wind energy potential assessment for the site of Inner Mongolia in China. Renew Sust Energ Rev.; 21:215-28, 2013.

ZAHARIM A, RAZALI A M, ABIDIN RZ, SOPIAN K. Fitting of statistical distribution to wind speed data in Malaysia. European Journal Of Scientific Research; 26(1):6-12, 2009.

ZHANG J, CHOWDHURY S, MESSAC A, CASTILLO L. A multivariate and multimodal wind distribution model. Renew Energy; 51:436-447, 2013. 